\title{
The effects of source rocks and chemical weathering on the petrogenesis of siliciclastic sand from the Neto River (Calabria, Italy): implications for provenance studies
}

\author{
EMILIA LE PERA, * JOSÈ ARRIBAS, $\dagger$ SALVATORE CRITELLI $\ddagger$ and AMPARO TORTOSA $\dagger$ \\ *Consiglio Nazionale delle Ricerche - Istituto di Ricerca per la Protezione Idrogeologica nell'Italia \\ meridionale ed insulare, Via Cavour, 87030 Roges di Rende (CS), Italy (E-mail: lepera@irpi.cs.cnr.it) \\ $\uparrow$ Departamento de Petrologia y Geoquimica, Facultad de Ciencias Geologicas, Universidad Complutense \\ de Madrid, Madrid, Spain (E-mail: arribas@eucmax.sim.ucm.es) \\ $\ddagger$ Dipartimento di Scienze della Terra, Università della Calabria, 87036 Arcavacata di Rende (CS), Italy \\ (E-mail: critelli@unical.it)
}

\begin{abstract}
Plutonic and gneissic rocks of the Sila Massif in the uppermost portion of the Neto drainage basin (Calabria, Southern Italy) weather and erode under a humid Mediterranean climate. During the development of weathering profiles, a combination of chemical weathering and granular disintegration processes occurred. Chemical weathering involves a loss of both plagioclase (mainly during grus generation) and K-feldspar (mainly during soil formation). This loss is attributed to transformation of plagioclase to clay minerals and to leaching and dissolution of K-feldspar. Sand composition is quartzofeldspathic and nearly homogeneous along the main channel of the Neto River, even where the river cuts across a blanket of sedimentary cover. Thus, fluvial transport does not alter sand composition within the Neto drainage basin. Petrographic indices are effective in (1) discriminating between contributions from similar (granite and gneiss) source rocks $(\mathrm{Qm} / \mathrm{F})$; (2) relating the provenance of plutoniclastic and gneissiclastic sand found in the headwaters to grus horizons $(\mathrm{Qm} / \mathrm{F} ; \mathrm{Q} / \mathrm{Rg})$; and (3) distinguishing between upstream first-cycle and downstream multicycle sand $(\mathrm{Q} / \mathrm{Rg})$. This last distinction is further emphasized by considering both aphanitic and phaneritic varieties of rock fragments (RgRmRs diagram). Chemical weathering is the main sand producer within the regolithic environment in northern Calabria. In addition, rapid erosion resulting from steep slopes removes weathered products, and rapid and short transport leads to minimal sediment maturation. In general, the F/Q index is climate and relief dependent; thus, it should be used in conjunction with palaeoclimatic and palaeophysiographic evidence for provenance interpretations of ancient quartzofeldspathic sandstones.
\end{abstract}

Keywords Calabria, chemical weathering, fluvial basin, Italy, provenance, sand, weathering profiles.

\section{INTRODUCTION}

Sand detrital modes reflect the cumulative effects of source rock composition, chemical weathering, hydraulic sorting and abrasion (Suttner, 1974; Basu, 1985; Johnsson, 1993; Nesbitt et al., 1996).
The effect of chemical weathering depends on both the intensity, controlled primarily by climate and vegetation, and the duration of weathering, this latter effect including a complex set of factors, of which physiography is particularly important (Valloni, 1985; Johnsson, 1993). The 
correlation of sand composition with weathering intensity (Mann \& Cavaroc, 1973; Basu, 1976; James et al., 1981; Suttner et al., 1981; Velbel, 1985; Cullers et al., 1988; Girty, 1991) and weathering duration (Franzinelli \& Potter, 1983; Grantham \& Velbel, 1988; Stallard, 1988; Johnsson \& Stallard, 1989; Johnsson, 1990a,b, 1993; Le Pera \& Sorriso-Valvo, 2000a) has long been established. Moreover, parent rock texture has also been shown to affect sand composition (Heins, 1993; Palomares \& Arribas, 1993).
The uppermost portion of the Neto drainage basin (eastern Calabria, Italy) is underlain by deeply weathered plutonic and gneissic rocks exposed to a humid climate (Fig. 1). The area is an excellent site in which to study the generation of sand-sized particles derived from plutonic and gneissic source rocks affected by chemical weathering.

This study provides insight into the petrogenesis of modern siliciclastic sand, based upon the coupling of both climatic and physiographic controls. Knowledge of such coupling is import-
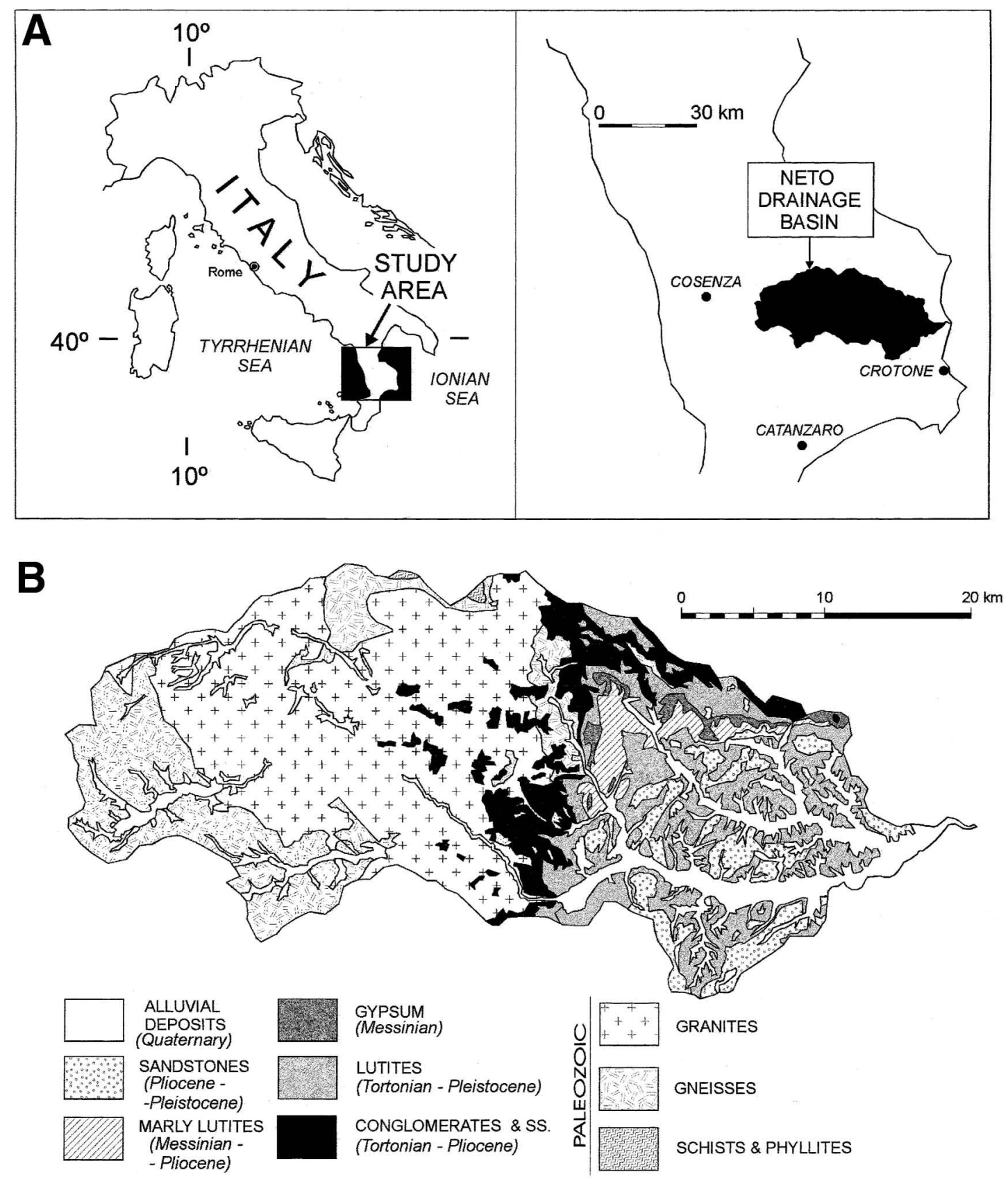

Fig. 1. (A) Location maps of the study area in northern Calabria, Italy. (B) Geological sketch map of the Neto drainage basin (modified after Amodio-Morelli et al., 1976). 
ant for the interpretation of analogous clastic deposits in the geological record.

\section{THE NETO DRAINAGE BASIN}

\section{Bedrock geology and mineralogy}

The Neto drainage basin is located in the Sila Massif, Calabria, Italy (Fig. 1A). The Sila Massif is a section of the Hercynian orogenic belt of western Europe, where allochthonous crystalline basement rocks are now exposed to form the highest tectonic units (Calabrian arc) of the southern Italy fold-thrust belt (Amodio-Morelli et al., 1976). The Sila Massif consists of Palaeozoic intrusive and metamorphic rocks, locally with an unmetamorphosed, Mesozoic sedimentary cover. Towards the Ionian coast, Miocene to Pleistocene sedimentary deposits lie unconformably over the Palaeozoic or Mesozoic rocks.

Palaeozoic rocks consist of gneiss, amphibolite, schist and phyllite, affected by various Alpine metamorphic events and intruded by the Late Hercynian Sila batholith (Messina et al., 1991). Gneisses consist of decimetre- to metre-thick biotite-sillimanite-garnet-rich layers, varying in structure from massive to migmatitic. Contacts with plutons are marked by a network of dikes and an irregular amphibolite facies thermal aureole (Caggianelli et al., 1994). The Sila batholith consists of multiple intersecting intrusions, heterogeneous in texture and fabric, ranging in composition from granodiorite to gabbro and leucomonzogranite (Messina et al., 1991). Fission track analyses of apatite and zircon from the basement rocks of the Sila Massif indicate a major period of exhumation ranging from $\approx 35$ to $\approx 15 \mathrm{Ma}$ (Thomson, 1994).

A section of Miocene to Pleistocene sedimentary rocks, $2000 \mathrm{~m}$ in thickness, crops out along the eastern border of the Sila Massif (Roda, 1964; Critelli, 1999). This section consists of (a) Miocene shallow-marine and turbiditic strata (Roveri et al., 1992), including arkose, hybrid arenite and calcarenite (Critelli \& Le Pera, 1998) and conglomerate; (b) Messinian evaporitic deposits (limestone, gypsum and halite; Roda, 1964); (c) Late Messinian to Pliocene conglomerate and sandstone, overlain by basin-wide marine shales (Roda, 1964; Roveri et al., 1992); and (d) Pleistocene shallow-marine calcarenites and non-marine clastics (Cosentino et al., 1989).

Throughout most of its length, the main channel of the Neto River system drains plutonic rocks, whereas the Ampollino and Arvo tributaries (Fig. 2A) mainly drain gneissic rocks. The lower reaches of the Neto cut across Miocene to Pleistocene sedimentary cover (Fig. 1B).

\section{Physiography, climate, soil development and human pressure}

The elevation of the Neto River basin ranges from sea level to $1928 \mathrm{~m}$ (Mount Botte Donato) at the western border. The watershed includes four small tributaries, the Ampollino, Arvo, Lese and Garga rivers (Fig. 2A). The drainage basin can be subdivided into three portions (upstream, downstream and delta system), each portion having distinctive morphological, hydrological and geological characteristics (Figs 1B, and 2). The uppermost portion of the watershed includes the rolling highlands of the Sila Massif, where the modern-day landscape is little modified with respect to the low relief that characterized it before early Pleistocene tectonic uplift (Le Pera \& Sorriso-Valvo, 2000a). The morphology of topographic slopes is controlled by low-rate mass-wasting processes and, as a result, the regolith, sometimes reaching a thickness of several tens of metres, has not yet been eroded (Critelli et al., 1991; Le Pera, 1998; Le Pera et al., 2000). The main reaches of the drainage system are gently sloping and very sinuous, with several sites acting as storage areas for alluvial deposits. A sharp decrease in the overall topographic slope marks the transition to the downstream area where Miocene siliciclastic deposits crop out (Figs $1 \mathrm{~B}$ and $2 \mathrm{~B}$ ). In this part of the drainage basin, the morphology of topographic slopes is rugged. In the downstream portion, the drainage system presents a wide, braided alluvial plain. Alluvial sedimentation, in the form of gravelly sand, is widespread throughout the coastal plain. Sand accumulates at the southern portion of the Neto delta system.

The Mediterranean climate of Calabria is zoned according to elevation and is generally humid above $1000 \mathrm{~m}$. The average annual precipitation $(1176 \mathrm{~mm}$ ) ranges from $600 \mathrm{~mm}$ at the Neto delta to more than $2000 \mathrm{~mm}$ in the mountainous areas (Versace et al., 1989). The mean annual temperature at about $2000 \mathrm{~m}$ is between $10^{\circ} \mathrm{C}$ and $12{ }^{\circ} \mathrm{C}$, but ranges from $12{ }^{\circ} \mathrm{C}$ to more than $16{ }^{\circ} \mathrm{C}$ for the coastal zone (Versace et al., 1989).

Vegetation is strongly correlated with precipitation and elevation. The uppermost portion of the Neto watershed maintains a well-developed forest cover of fir and beech trees. With decreasing precipitation, the hillslopes of the lower 


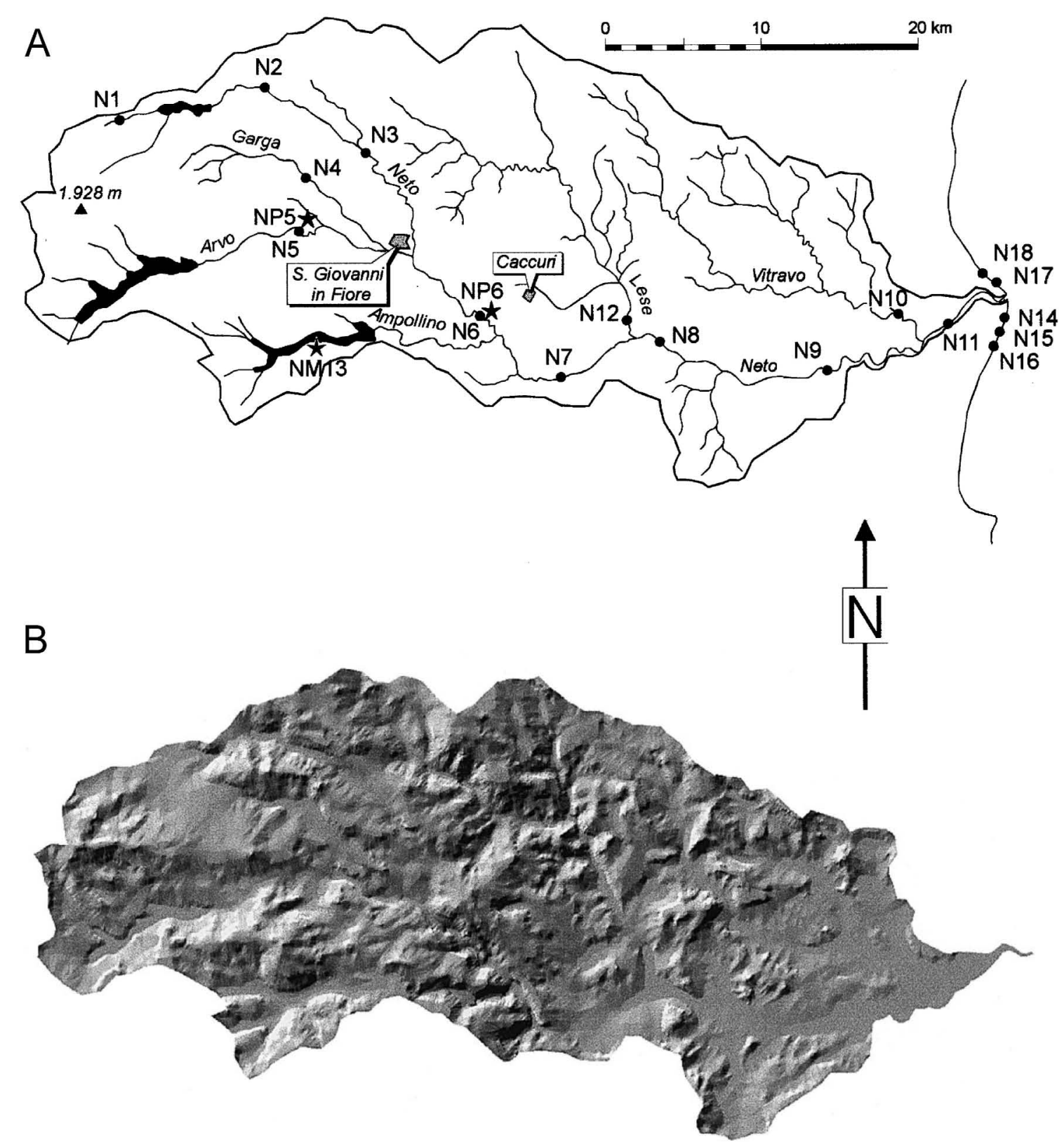

Fig. 2. (A) Drainage network of the Neto River showing the location of weathering profiles examined (stars), as well as collection sites for fluvial and coastal sand samples (black circles). (B) Digital elevation model (DEM) of the study area. Slopes are emphasized using a north-west illumination.

portions of the basin give way to Mediterranean macchia (grass and shrub cover).

A thick mantle of residual weathered products covers the Palaeozoic crystalline bedrock. In the Sila Massif, drilling has intersected weathered material at depths up to $60 \mathrm{~m}$ (Critelli et al., 1991; Le Pera et al., 2000). Weathering on the Sila Massif may have started in the Late CenozoicQuaternary (Nossin, 1972).

The stages of weathering of the Neto crystalline basement rocks are characterized by discolour- ation, staining, mineral alteration and textural change. Complete weathering profiles consist of organic soil horizons above a thicker layer of grus, which in turn give way to fresh bedrock below. In this paper, the term grus is defined as the fragmental product of in situ granular disintegration of granitic rocks (e.g. Bates \& Jackson, 1987). For simplicity, the term grus is also used for the saprolitic layers developed on gneissic profiles. Organic soil horizons $(<0.5 \mathrm{~m}$ thick $)$ are dark brown and mostly have a medium to fine sandy 
texture. Grus horizons ( $>10 \mathrm{~m}$ thick) commonly preserve original plutonic or gneissic fabrics and crush readily under hand pressure. Towards the base of the profile, relatively unweathered corestones of fresh rock are typical (Le Pera \& SorrisoValvo, 2000b).

Calabria has been a site of human activity since preMagna Graecia times. Anthropogenic deforestation has greatly influenced the landscape evolution of Mediterranean countries (e.g. Nir, 1983). Deforestation increased considerably subsequent to the eighth century BC and is assumed to have been one of the main causes of river bed aggradation. The increased erosional regime is responsible for the progressive change in fluvial regimes in Calabria, from perennial to torrential, with braided coarse-grained channel beds and steep longitudinal profiles (Sorriso-Valvo, 1997). Indeed, during Greek times, some of the Calabrian rivers still had estuarine debouching.

Deforestation and agricultural expansion became increasingly widespread during the Roman age until the fifth century AD. With the decline of the Roman Empire in the sixth century, most of the population living on the coasts moved inland to safer places, creating inland deforestation, agricultural expansion and mountain stream control walls (check-dams) on the highest slopes of the mountains (Sorriso-Valvo, 1993, 1997).

The Calabria region has been and continues to be one of the least developed regions in Italy. In the modern age, deforestation appears to have occurred with high intensity in the seventeenth and eighteenth centuries and again in the first half of the twentieth century (Sorriso-Valvo et al., 1998). However, because of the absence of industrial settlements, the Calabria region today ranks fourth in Italy for its percentage of forest-covered land (34\%; Sorriso-Valvo, 1993). In the past few decades, the general trend in the region is one of accelerated river, slope and coastal erosion.

Although the Neto River drainage basin has seen little urbanization and no industrial development, it cannot be considered a pristine drainage basin. Human disturbance (i.e. grazing and tilling) of sedimentary processes is low in the upland area of the basin, whereas agricultural expansion and urbanization are increasingly widespread in the lower reaches of the basin, dramatically increasing river and coastal erosion and mass movement. The sample suite presented here represents an opportunity to evaluate the effects of weathered source rocks on fluvial sediment composition in the region before anthropogenic activity obliterates the natural environmental signal (e.g. Johnsson et al., 1993; Morton \& Johnsson, 1993).

\section{PROCEDURES}

A total of 27 samples were collected (Fig. 2A). Thirteen are sands from the main channel of the Neto River and its four principal tributaries near the confluence with the main trunk stream. These samples were taken from active subaqueous deposits such as longitudinal bars. Five sand samples were collected from the high-tide berm of the Neto delta system. Finally, three sets of samples were obtained from weathering profiles developed on the Sila batholith. Each set from the weathering profiles consists of three samples: crystalline bedrock, grus and soil horizon. Two sets are from granodiorite (NP5a, NP5b and NP5c) and monzogranite (NP6a, NP6b and NP6c), and one set is from gneiss (NM13a, NM13b and NM13c).

Sand samples were washed with dilute $\mathrm{H}_{2} \mathrm{O}_{2}$ to remove organic matter, air dried and sieved (using $1 \Phi$ intervals from 4 to $0.062 \mathrm{~mm}$ ). The medium sand fraction (0.50-0.25 mm) was cemented with epoxy and thin sectioned. Each thin section was etched with HF and stained by immersion in sodium cobaltinitrite solution to allow the identification of feldspars. Alizarine and potassium Fe-cyanide solutions were used for carbonate identification. To analyse the modal composition of the medium-sized fraction, more than 400 points were counted in each thin section according to the Gazzi-Dickinson method (Gazzi, 1966; Dickinson, 1970; Ingersoll et al., 1984; Zuffa, 1985).

Fresh crystalline bedrock samples (NP5a, NP6a and NM13a) from the weathering profiles were crushed and sieved to obtain the $0 \cdot 5$ - to $0.25-\mathrm{mm}$ sand fraction. The composition of this artificial sand was obtained according to the same procedure used for natural sands. The resulting detrital modes were used as the starting point in the compositional evolution of the weathering profiles. An additional point count of 200 feldspar grains (100 K-feldspar and 100 plagioclase) was carried out to discriminate different alteration stages.

Data for evaluating the source of each fluvial sand sample were acquired using a geographic information system (Ilwis $4 \cdot 0$ ). Topographic maps (scale: 1:200 000) were digitized to obtain, by rasterization and interpolation, a digital elevation model (DEM; Fig. 2B). In turn, the DEM was filtered to produce a slope map. Information about lithology was obtained from geological maps 
(1:25 000 scale) by digitizing the different lithologies as polygons. Thus, a given area can be analysed in terms of the distribution of the different lithologies and their median slope values. The subbasin of a given fluvial sand is considered as that portion of the drainage basin involved in the genesis of that sample (Arribas et al., 2000). Thus, each fluvial sample is directly related to a distribution of lithologies at its source, including absolute $\left(\mathrm{km}^{2}\right)$ or relative (\%) values and a median slope value (\%) for each bedrock type (Table 1).

\section{GRAIN-SIZE ANALYSIS}

Grain-size analyses of the 4- to 0.062-mm fraction were carried out on the three weathering profiles (grus, soil) and on one fluvial sample derived directly from the NP6 weathering profile (Fig. 3). Gneissic and granitic grus horizons show equivalent grain-size distributions, characterized by modes in the coarser fractions $(>2 \mathrm{~mm})$ and a progressive diminution of frequencies as grain size decreases. High values of positive skewness (0.28-0.56; from positive to strongly positive skewness) and standard deviation (1.34-1.84; poorly sorted) are the main characteristics of these horizons. Granitic soils have a similar grainsize distribution to that of associated grus. However, in soil generated from gneissic bedrock (sample NM13c), the mode shifts towards coarse sand. This shift in mode indicates that granular disintegration is an important process during soil development on gneissic bedrock (Le Pera \& Sorriso-Valvo, 2000b).

The weathering products seem to have a grain-size distribution close to a Rosin distribution (McEwen et al., 1959) because of its 'sourcerock' control (e.g. Kittleman, 1964; Ibbeken, 1983; Schleyer, 1987; Ibbeken \& Schleyer, 1991).

Finally, fluvial deposits from a single granitic source, directly related to the NP6 profile, show a symmetrical grain-size distribution with a coarsesand mode and moderate sorting. These changes with respect to associated weathering products can be explained by hydraulic sorting of sediment during incorporation into the fluvial system.

\section{GRAIN TYPES}

The most abundant grains in the medium-sized fraction of sands from the Neto drainage basin are monocrystalline quartz, K-feldspar, plagioclase, mica and plutonic/gneissic rock fragments.

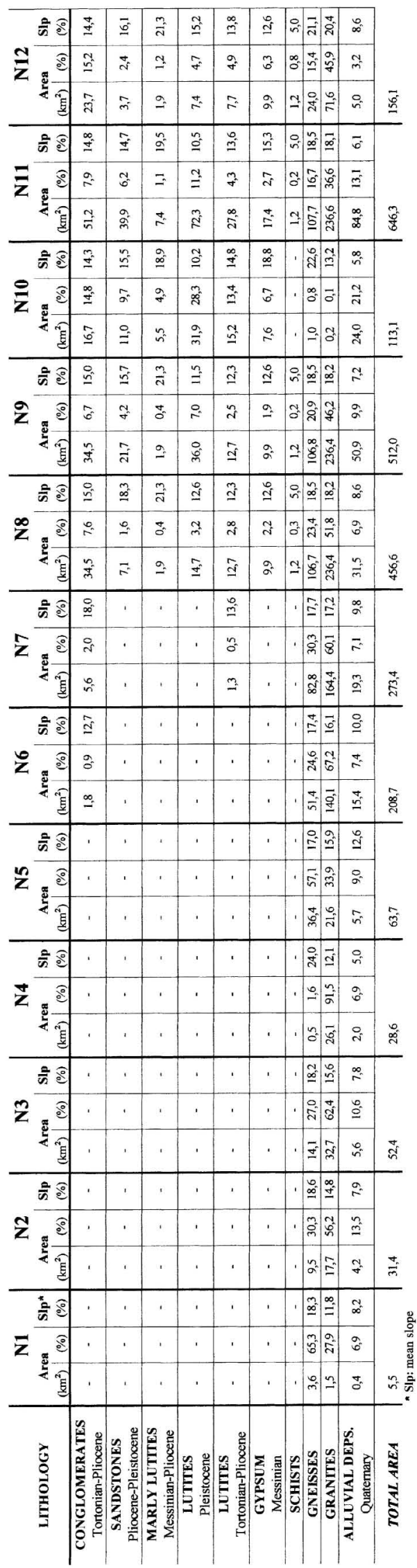


Table 2. Results of petrographic modal analysis.

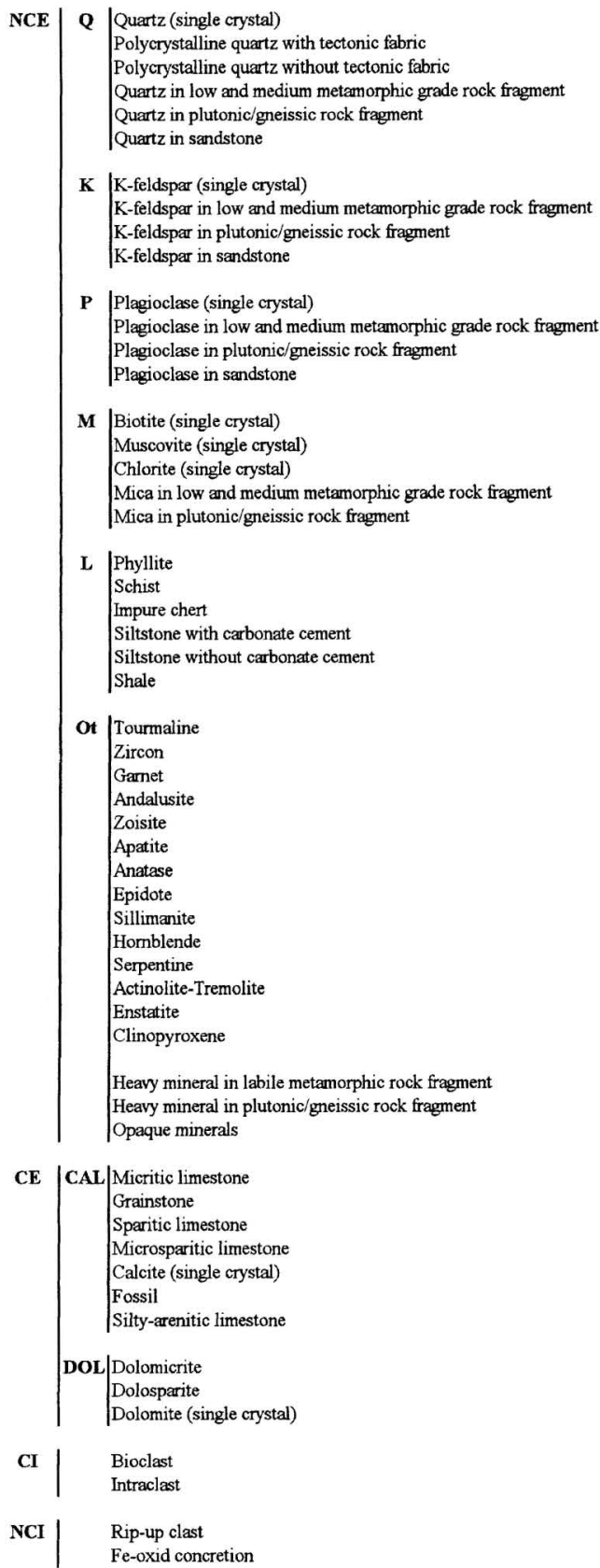

\begin{tabular}{|c|c|c|c|c|c|c|c|c|c|c|c|c|c|}
\hline N-1 & $\mathrm{N}-2$ & N-3 & $\mathrm{N}-4$ & N-5 & $\begin{array}{c}\text { NP- } \\
5 a\end{array}$ & $\begin{array}{c}\text { NP- } \\
\mathbf{5 b}\end{array}$ & $\begin{array}{c}\text { NP- } \\
5 c\end{array}$ & N-6 & $\begin{array}{c}\text { NP- } \\
6 a\end{array}$ & $\begin{array}{c}\text { NP- } \\
6 b\end{array}$ & $\begin{array}{c}\text { NP- } \\
6 c\end{array}$ & $\begin{array}{c}\text { NP- } \\
6 d\end{array}$ & N-7 \\
\hline 34,5 & 27,3 & 37,3 & 34,6 & 27,8 & 25,2 & 30,8 & 34,2 & 31,1 & 27,4 & 24,7 & 24,5 & 28,2 & 32,7 \\
\hline 3,4 & 2,8 & 0,5 & 0,5 & 0,4 & 0,2 & 0,0 & 0,2 & 0,2 & 0,5 & 0,7 & 0,0 & 0,5 & 0,5 \\
\hline 3,2 & 7,2 & 2,7 & 3,1 & 1,1 & 3,9 & 1,4 & 0,5 & 3,2 & 3,8 & 1,9 & 1,7 & 1,4 & 1,9 \\
\hline 0,0 & 0,7 & 1,0 & 0,9 & 0,2 & 0,0 & 0,0 & 0,0 & 0,0 & 0,0 & 0,0 & 0,0 & 0,0 & 0,0 \\
\hline 5,1 & 5,3 & 4,8 & 1,6 & 2,7 & 7,0 & 2,4 & 3,0 & 4,1 & 5,5 & 5,1 & 2,8 & 4,9 & 6,3 \\
\hline 0,0 & 0,0 & 0,0 & 0,0 & 0,0 & 0,0 & 0,0 & 0,0 & 0,0 & 0,0 & 0,0 & 0,0 & 0,0 & 0,0 \\
\hline 7,8 & 19,9 & 20,7 & 18,6 & 8,2 & 3,9 & 5,0 & 7,3 & 17,5 & 14,7 & 16,3 & 10,4 & 11,0 & 19,2 \\
\hline 0,0 & 0,9 & 0,0 & 0,0 & 0,0 & 0,0 & 0,0 & 0,0 & 0,0 & 0,0 & 0,0 & 0,0 & 0,0 & 0,0 \\
\hline 3,7 & 8,3 & 4,6 & 4,9 & 0,4 & 1,7 & 4,7 & 1,4 & 5,8 & 9,1 & 8,4 & 5,4 & 7,5 & 4,3 \\
\hline 0,0 & 0,0 & 0,0 & 0,0 & 0,0 & 0,0 & 0,0 & 0,0 & 0,0 & 0,0 & 0,0 & 0,0 & 0,0 & 0,0 \\
\hline 6,8 & 13,9 & 12,0 & 18,4 & 16,8 & 30,3 & 14,7 & 18,0 & 20,1 & 18,3 & 18,6 & 14,2 & 26,3 & 19,2 \\
\hline 0,0 & 0,0 & 0,2 & 0,0 & 0,0 & 0,0 & 0,0 & 0,0 & 0,0 & 0,0 & 0,0 & 0,0 & 0,0 & 0,0 \\
\hline 2,4 & 4,6 & 4,1 & 4,2 & 3,2 & 5,8 & 3,8 & 1,6 & 4,1 & 9,6 & 6,3 & 5,7 & 6,6 & 3,4 \\
\hline 0,0 & 0,0 & 0,0 & 0,0 & 0,0 & 0,0 & 0,0 & 0,0 & 0,0 & 0,0 & 0,0 & 0,0 & 0,0 & 0,0 \\
\hline 10,8 & 4,8 & 8,9 & 8,7 & 23,4 & 16,7 & 32,0 & 25,1 & 10,7 & 1,9 & 7,7 & 28,5 & 9,4 & 7,9 \\
\hline 2,7 & 0,2 & 0,5 & 0,0 & 0,2 & 0,0 & 0,0 & 0,0 & 0,5 & 5,3 & 3,7 & 1,2 & 0,5 & 0,7 \\
\hline 0,2 & 0,0 & 0,0 & 0,0 & 0,0 & 0,0 & 0,0 & 0,0 & 0,0 & 0,0 & 4,4 & 0,9 & 0,0 & 0,2 \\
\hline 0,0 & 0,0 & 0,5 & 0,0 & 0,0 & 0,0 & 0,0 & 0,0 & 0,0 & 0,0 & 0,0 & 0,0 & 0,0 & 0,0 \\
\hline 4,9 & 1,2 & 1,7 & 2,6 & 2,1 & 2,2 & 0,7 & 2,3 & 1,7 & 3,1 & 1,9 & 2,1 & 2,1 & 1,9 \\
\hline 1,2 & 0,2 & 0,0 & 0,0 & 2,5 & 0,0 & 0,0 & 0,0 & 0,5 & 0,0 & 0,0 & 0,0 & 0,7 & 0,5 \\
\hline 0,5 & 0,0 & 0,0 & 0,0 & 0,0 & 0,0 & 0,0 & 0,0 & 0,0 & 0,0 & 0,0 & 0,0 & 0,0 & 0,0 \\
\hline 0,0 & 0,2 & 0,0 & 0,0 & 0,2 & 0,0 & 0,0 & 0,0 & 0,0 & 0,0 & 0,0 & 0,0 & 0,2 & 0,0 \\
\hline 0,0 & 0,0 & 0,0 & 0,0 & 0,0 & 0,0 & 0,0 & 0,0 & 0,0 & 0,0 & 0,0 & 0,0 & 0,0 & 0,0 \\
\hline 0,0 & 0,0 & 0,0 & 0,0 & 0,0 & 0,0 & 0,0 & 0,5 & 0,0 & 0,0 & 0,0 & 0,0 & 0,0 & 0,0 \\
\hline 0,0 & 0,2 & 0,0 & 0,0 & 0,0 & 0,0 & 0,0 & 0,0 & 0,0 & 0,0 & 0,0 & 0,0 & 0,0 & 0,0 \\
\hline 0,0 & 0,0 & 0,0 & 0,0 & 0,4 & 0,0 & 0,5 & 0,0 & 0,0 & 0,0 & 0,0 & 0,0 & 0,0 & 0,0 \\
\hline 0,5 & 0,0 & 0,0 & 0,0 & 0,0 & 0,0 & 0,0 & 0,2 & 0,0 & 0,0 & 0,0 & 0,0 & 0,0 & 0,0 \\
\hline 4,4 & 0,0 & 0,0 & 0,0 & 0,2 & 0,0 & 0,0 & 0,0 & 0,0 & 0,0 & 0,0 & 0,0 & 0,0 & 0,0 \\
\hline 0,2 & 0,0 & 0,0 & 0,0 & 0,0 & 0,0 & 0,2 & 0,2 & 0,0 & 0,0 & 0,0 & 0,0 & 0,0 & 0,2 \\
\hline 0,2 & 0,0 & 0,0 & 0,0 & 0,0 & 0,0 & 0,0 & 0,5 & 0,0 & 0,0 & 0,0 & 0,0 & 0,0 & 0,0 \\
\hline 0,2 & 0,0 & 0,0 & 0,0 & 0,0 & 0,0 & 0,0 & 0,0 & 0,0 & 0,0 & 0,0 & 0,0 & 0,0 & 0,0 \\
\hline 0,7 & 0,0 & 0,0 & 0,2 & 0,0 & 0,0 & 0,0 & 0,0 & 0,0 & 0,0 & 0,0 & 0,0 & 0,0 & 0,0 \\
\hline 0,7 & 0,0 & 0,0 & 0,0 & 1,3 & 0,5 & 0,2 & 0,0 & 0,2 & 0,0 & 0,0 & 0,5 & 0,0 & 0,2 \\
\hline 0,2 & 0,2 & 0,0 & 0,0 & 0,4 & 0,0 & 0,0 & 0,0 & 0,0 & 0,0 & 0,0 & 0,0 & 0,0 & 0,0 \\
\hline 0,5 & 0,2 & 0,0 & 0,9 & 5,5 & 1,9 & 0,9 & 1,4 & 0,0 & 0,2 & 0,0 & 0,9 & 0,0 & 0,2 \\
\hline 0,0 & 0,9 & 0,0 & 0,0 & 0,2 & 0,0 & 0,0 & 0,0 & 0,0 & 0,0 & 0,2 & 0,0 & 0,0 & 0,0 \\
\hline 0,0 & 0,0 & 0,0 & 0,0 & 0,6 & 0,0 & 0,0 & 0,0 & 0,0 & 0,0 & 0,0 & 0,0 & 0,0 & 0,0 \\
\hline 0,0 & 0,0 & 0,0 & 0,0 & 0,0 & 0,0 & 0,7 & 0,2 & 0,0 & 0,0 & 0,0 & 0,0 & 0,0 & 0,0 \\
\hline 0,0 & 0,0 & 0,0 & 0,0 & 0,0 & 0,0 & 0,0 & 0,9 & 0,0 & 0,0 & 0,0 & 0,0 & 0,0 & 0,0 \\
\hline 0,0 & 0,9 & 0,2 & 0,2 & 0,0 & 0,0 & 0,0 & 0,0 & 0,0 & 0,0 & 0,0 & 0,0 & 0,0 & 0,0 \\
\hline 0,0 & 0,0 & 0,0 & 0,0 & 1,3 & 0,5 & 0,5 & 0,0 & 0,0 & 0,0 & 0,0 & 0,5 & 0,2 & 0,0 \\
\hline 4,9 & 0,0 & 0,2 & 0,5 & 0,8 & 0,0 & 0,2 & 0,7 & 0,2 & 0,0 & 0,0 & 0,7 & 0,2 & 0,2 \\
\hline 0,0 & 0,0 & 0,0 & 0,0 & 0,0 & 0,0 & 0,0 & 0,0 & 0,0 & 0,0 & 0,0 & 0,0 & 0,0 & 0,0 \\
\hline 0,0 & 0,0 & 0,0 & 0,0 & 0,0 & 0,0 & 0,0 & 0,0 & 0,0 & 0,0 & 0,0 & 0,0 & 0,0 & 0,0 \\
\hline 0,0 & 0,0 & 0,0 & 0,0 & 0,0 & 0,0 & 0,0 & 0,0 & 0,0 & 0,0 & 0,0 & 0,0 & 0,0 & 0,0 \\
\hline 0,0 & 0,0 & 0,0 & 0,0 & 0,0 & 0,0 & 0,0 & 0,0 & 0,0 & 0,0 & 0,0 & 0,0 & 0,0 & 0,0 \\
\hline 0,0 & 0,0 & 0,0 & 0,0 & 0,0 & 0,0 & 0,0 & 0,0 & 0,0 & 0,5 & 0,0 & 0,0 & 0,0 & 0,0 \\
\hline 0,0 & 0,0 & 0,0 & 0,0 & 0,0 & 0,0 & 0,0 & 0,0 & 0,0 & 0,0 & 0,0 & 0,0 & 0,0 & 0,0 \\
\hline 0,0 & 0,0 & 0,0 & 0,0 & 0,0 & 0,0 & 0,0 & 0,0 & 0,0 & 0,0 & 0,0 & 0,0 & 0,0 & 0,0 \\
\hline 0,0 & 0,0 & 0,0 & 0,0 & 0,0 & 0,0 & 0,0 & 0,0 & 0,0 & 0,0 & 0,0 & 0,0 & 0,0 & 0,0 \\
\hline 0,0 & 0,0 & 0,0 & 0,0 & 0,0 & 0,0 & 0,0 & 0,0 & 0,0 & 0,0 & 0,0 & 0,0 & 0,0 & 0,2 \\
\hline 0,0 & 0,0 & 0,0 & 0,0 & 0,0 & 0,0 & 0,0 & 0,0 & 0,0 & 0,0 & 0,0 & 0,0 & 0,0 & 0,0 \\
\hline 0,0 & 0,0 & 0,0 & 0,0 & 0,0 & 0,0 & 0,0 & 0,0 & 0,0 & 0,0 & 0,0 & 0,0 & 0,0 & 0,0 \\
\hline 0,0 & 0,0 & 0,0 & 0,0 & 0,0 & 0,0 & 0,0 & 0,0 & 0,0 & 0,0 & 0,0 & 0,0 & 0,0 & 0,0 \\
\hline 0,0 & 0,0 & 0,0 & 0,0 & 0,0 & 0,0 & 0,2 & 0,0 & 0,0 & 0,0 & 0,0 & 0,0 & 0,0 & 0,0 \\
\hline 0,0 & 0,0 & 0,0 & 0,0 & 0,0 & 0,0 & 0,9 & 1,8 & 0,0 & 0,0 & 0,2 & 0,0 & 0,2 & 0,0 \\
\hline 409 & 433 & 415 & 425 & 475 & 412 & 422 & 438 & 412 & 416 & 430 & 424 & 426 & 416 \\
\hline 67,3 & 47,2 & 52,6 & 46,9 & 50,7 & 46,6 & 55,1 & 56,8 & 44,5 & 41,9 & 39,5 & 44,9 & 40,1 & 47,0 \\
\hline 30,2 & 52,0 & 47,4 & 53,1 & 45,0 & 53,4 & 44,9 & 42,5 & 54,9 & 58,1 & 60,5 & 55,1 & 58,9 & 52,5 \\
\hline 2,5 & 0,8 & 0,0 & 0,0 & 4,3 & 0,0 & 0,0 & 0,7 & 0,6 & 0,0 & 0,0 & 0,0 & 1,1 & 0,5 \\
\hline 69,0 & 47,6 & 52,6 & 46,9 & 52,9 & 46,6 & 55,1 & 57,2 & 44,8 & 41,9 & 39,5 & 44,9 & 40,5 & 47,3 \\
\hline 17,2 & 32,1 & 28,8 & 27,1 & 14,2 & 7,1 & 15,5 & 13,1 & 27,0 & 26,8 & 30,1 & 24,5 & 21,5 & 26,9 \\
\hline 13,9 & 20,4 & 18,6 & 26,0 & 32,9 & 46,3 & 29,4 & 29,7 & 28,2 & 31,4 & 30,4 & 30,7 & 38,0 & 25,8 \\
\hline 90,4 & 86,6 & 88,7 & 91,9 & 78,0 & 100,0 & 100,0 & 94,7 & 97,0 & 98,3 & 100,0 & 100,0 & 96,8 & 95,7 \\
\hline 9,6 & 12,4 & 11,3 & 8,1 & 22,0 & 0,0 & 0,0 & 0,0 & 3,0 & 0,0 & 0,0 & 0,0 & 3,2 & 2,9 \\
\hline 0,0 & 1,0 & 0,0 & 0,0 & 0,0 & 0,0 & 0,0 & 5,3 & 0,0 & 1,7 & 0,0 & 0,0 & 0,0 & 1,4 \\
\hline 0,45 & 0,39 & 0,39 & 0,49 & 0,70 & 0,9 & 0,66 & 0,69 & 0,51 & 0,5 & 0,50 & 0,56 & 0,64 & 0,49 \\
\hline
\end{tabular}


Table 2. Continued.

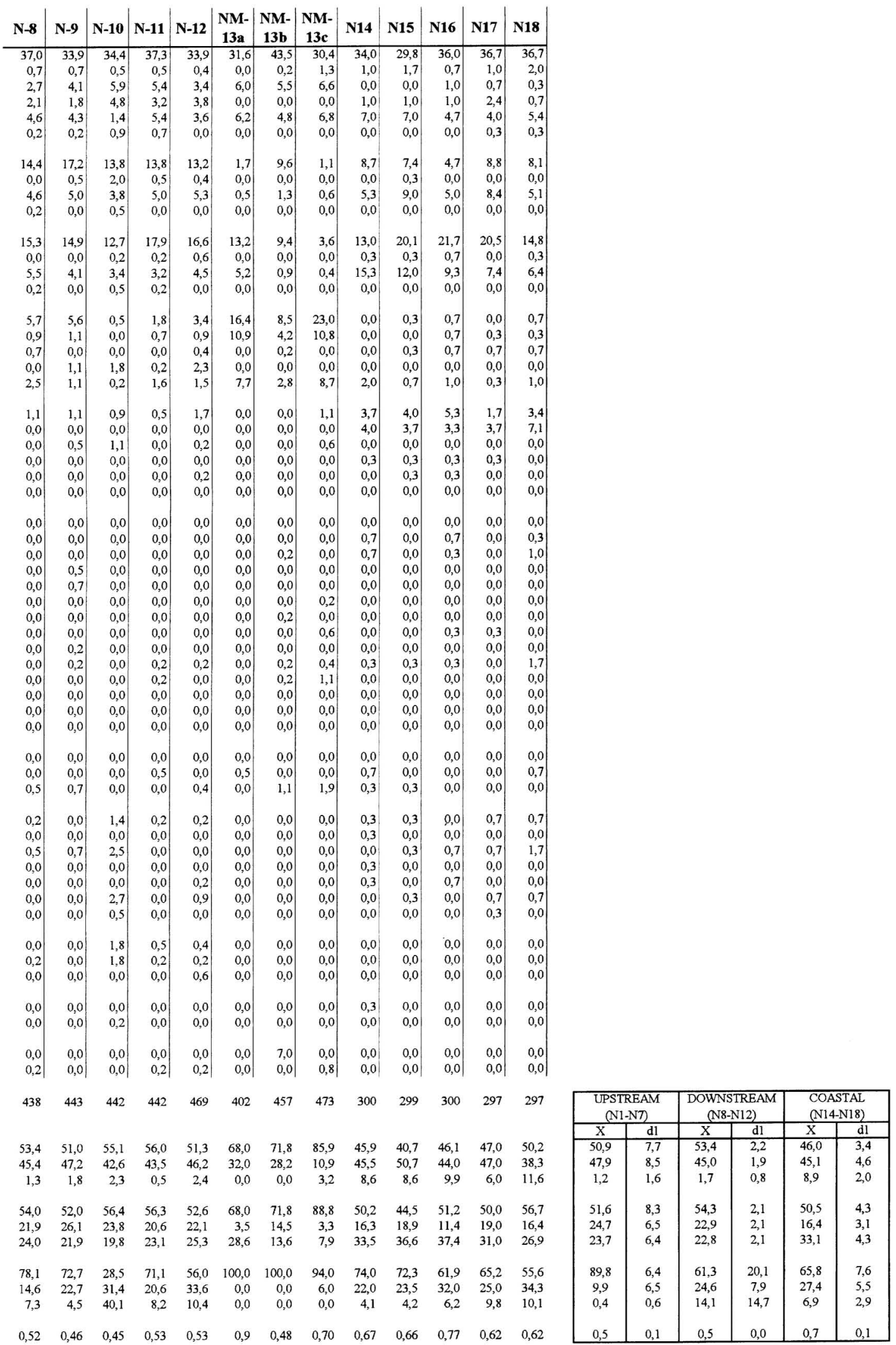




\begin{tabular}{|c|c|c|c|c|c|c|c|c|c|c|}
\hline & \multicolumn{5}{|c|}{$100 \%$ K-feldspar } & \multicolumn{5}{|c|}{$100 \%$ Plagioclase } \\
\hline & Ка & $\mathrm{Kb}$ & Kc & $\mathrm{Kd}$ & $\mathrm{Ke}$ & $\mathrm{Pa}$ & $\mathrm{Pb}$ & Pc & $\mathrm{Pd}$ & $\mathrm{Pe}$ \\
\hline N1 & 69 & 17 & 4 & 4 & 6 & 33 & 21 & 21 & 12 & 13 \\
\hline N2 & 94 & 4 & 0 & 2 & 0 & 22 & 27 & 31 & 20 & 0 \\
\hline N3 & 93 & 3 & 2 & 2 & 0 & 29 & 31 & 26 & 11 & 3 \\
\hline N4 & 85 & 9 & 2 & 2 & 2 & 24 & 29 & 24 & 19 & 4 \\
\hline N5 & 87 & 7 & 3 & 3 & 0 & 18 & 14 & 24 & 29 & 15 \\
\hline NP5a & 76 & 12 & 12 & 0 & 0 & 47 & 26 & 12 & 9 & 6 \\
\hline NP5b & 94 & 6 & 0 & 0 & 0 & 25 & 16 & 29 & 25 & 5 \\
\hline NP5c & 82 & 18 & 0 & 0 & 0 & 6 & 8 & 24 & 38 & 24 \\
\hline N6 & 78 & 9 & 9 & 4 & 0 & 11 & 24 & 24 & 34 & 7 \\
\hline NP6a & 86 & 12 & 2 & 0 & 0 & 13 & 40 & 37 & 7 & 3 \\
\hline NP6b & 96 & 4 & 0 & 0 & 0 & 14 & 35 & 39 & 6 & 6 \\
\hline NP6c & 85 & 10 & 5 & 0 & 0 & 19 & 32 & 36 & 8 & 5 \\
\hline NP6d & 82 & 15 & 3 & 0 & 0 & 9 & 19 & 41 & 25 & 6 \\
\hline N7 & 89 & 7 & 2 & 2 & 0 & 2 & 14 & 42 & 26 & 16 \\
\hline N8 & 86 & 7 & 7 & 0 & 0 & 9 & 39 & 34 & 9 & 9 \\
\hline N9 & 86 & 10 & 2 & 2 & 0 & 10 & 17 & 31 & 34 & 8 \\
\hline N10 & 85 & 13 & 2 & 0 & 0 & 9 & 25 & 27 & 30 & 9 \\
\hline N11 & 86 & 11 & 3 & 0 & 0 & 13 & 41 & 35 & 11 & 0 \\
\hline N12 & 94 & 4 & 2 & 0 & 0 & 9 & 19 & 54 & 11 & 7 \\
\hline NM13a & 73 & 27 & 0 & 0 & 0 & 39 & 30 & 28 & 3 & 0 \\
\hline NM13b & 82 & 16 & 2 & 0 & 0 & 29 & 23 & 21 & 23 & 4 \\
\hline NM13c & 61 & 11 & 17 & 0 & 11 & 33 & 21 & 23 & 10 & 13 \\
\hline
\end{tabular}

Table 3. Distribution of alteration degree of feldspars.
a. Unaltered grain.
b. Alteration $<\mathbf{1 0} \%$.
c. Alteration from 10 to $40 \%$.
d. Alteration $>40 \%$.
e. Totally altered grain.

stream sands (N8 to N18, except NM13) and show a wide spectrum of textures and compositions (Table 2). Fossils are also common and include globigerinids and bryozoans derived from sedimentary rocks (probably marls).

\section{Penecontemporaneous grains}

These include bioclasts from the Neto delta, intraclasts (irregularly shaped micritic aggregates, CI; Zuffa, 1980) and argillaceous grains and Fe-oxide concretions (NCI; Zuffa, 1980) interpreted as secondary alteration products, derived directly from the bedrock (Table 2). The high proportions of argillaceous grains in sample NM13b (7\%) support the interpretation that they are alteration products (alterite), which are very common in gneiss from the western Sila border (Critelli et al., 1991; Critelli \& Le Pera, 2000; Le Pera et al., 2001; Le Pera \& SorrisoValvo, 2000a). Fe-oxide concretions can also be related to pedogenic processes (Johnsson \& Stallard, 1989; Johnsson, 1990a), and only wellindurated particles are present in the Neto fluvial sand.

\section{PETROGRAPHIC COMPOSITION}

\section{Rocks, grus and soil sand fraction}

Weathering profiles investigated during this study are developed in areas with different topographic relief. The profile at site NM13 (Fig. 2a) developed on gneiss along the southern slope of Ampollino Lake. There, slope gradients are moderate (mean 25\%, compare Fig. $2 \mathrm{~A}$ and B). Weathering profiles developed on plutonic rocks are located near the Arvo River and near the mid-course of the Neto River (NP5 and NP6 respectively). The NP5 site in the headwaters of the drainage basin is characterized by gentle slopes (from $14 \%$ to $17 \%$ ), whereas at site NP6, slopes are steeper (mean 31\%).

At NP5, the bedrock is composed of coarsegrained granodiorite. Hornblende and chloritized biotite are the dominant ferromagnesian minerals. Strained quartz and zoned plagioclase with sericitized cores are common. Coarse-grained monzogranite is the parent rock of the weathering profile developed at site NP6. Quartz is slightly strained, and plagioclase appears as unzoned 
crystals showing homogeneous alteration to sericite, whereas biotite is minor and frequently chloritized. Cordierite-bearing gneiss at site NM13 has large amounts of muscovite and plagioclase. Biotite is minor, and K-feldspar is very rare. Quartz is slightly strained, and cordierite is frequently transformed to white mica.

Petrographic analysis of artificial sand (obtained by crushing unaltered bedrock samples; NP5a, NP6a and NM13a; Table 2) is used to represent the starting point of weathering trends (Figs 4 and 5). The three bedrock samples are quartzofeldspathic. The amount of feldspar differs between plutonic and gneissic rocks (53-58-32\% of QmFLt\%F respectively). Plagioclase is the dominant feldspar in artificial sand from both gneiss and granodiorite, with $\mathrm{P} / \mathrm{F}$-values of $0 \cdot 9$, whereas in monzogranitic sand, $\mathrm{P} / \mathrm{F}$ is 0.5 (Table 2 ).

Quantitative changes in the proportions of quartz and feldspar between bedrock and grus are characterized by an increase in monocrystalline quartz grains (from $2 \%$ to $8 \%$ of QmFLt\%Qm; Fig. 4) and a decrease in plagioclase content (from $2 \%$ to $17 \%$ of QmKP\%P; Fig. 5). Trends marking the rapid loss of plagioclase grains during grus generation have long been documented (Todd, 1968; Nesbitt \& Young, 1989; Banfield
\& Eggleton, 1990; Girty, 1991; Nesbitt et al., 1996, 1997; Critelli \& Le Pera, 2000; Le Pera \& SorrisoValvo, 2000a,b). Differences in composition between grus and soil sand are marked by an increase in monocrystalline quartz grains (2$14 \%$ of QmFLt $\%$ Qm) and a reduction in K-feldspar $(2-11 \%$ of $\mathrm{QmKP} \% \mathrm{~K})$. This trend results in substantial modifications to quartz-K-feldsparplagioclase proportions before detritus ever enters the fluvial system and is generated as chemical weathering proceeds through reactions of inorganic and organic acids with bedrock minerals (Nesbitt \& Young, 1984; Nesbitt et al., 1997). Particularly in the uppermost portion of the weathering profiles, the dissolution mechanism of K-feldspar has been related to the uptake of potassium and other nutrient elements by plants (Basu, 1981; Moulton \& Berner, 1998), lichens (McCarroll, 1990) and soil microorganisms (Huang \& Keller, 1972). Compositional divergence, through analysed weathering profiles, could be related to the balance between duration of weathering and rates of erosion (Nesbitt et al., 1997). Thus, the profile at site NP6, characterized by minor mineralogical changes between bedrock and soil sand, could be related to a more rugged topography than that of sites NP5 and NM13.

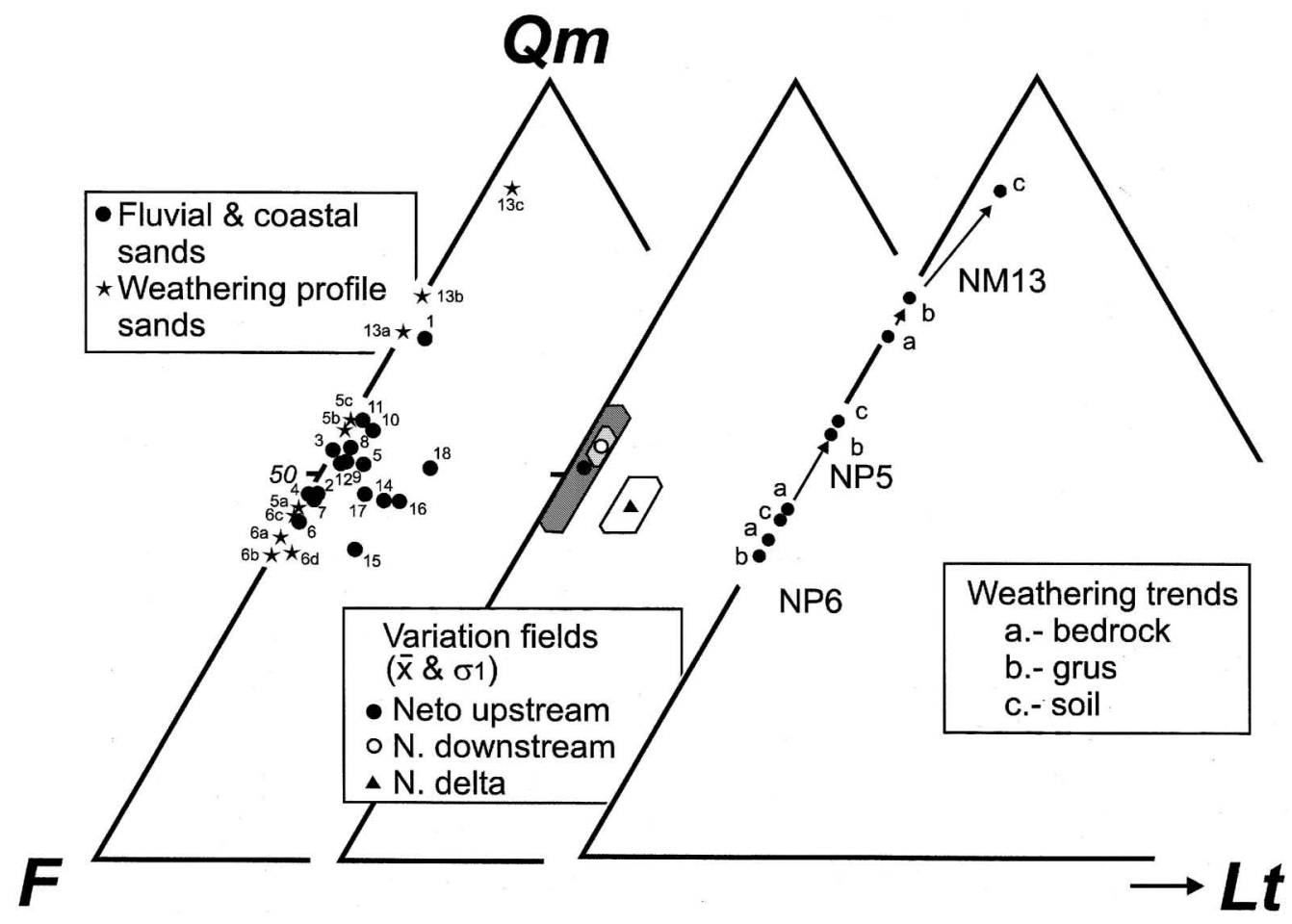

Fig. 4. QmFLt diagram showing sand composition (point count data) of samples from the Neto basin. Weathering profiles are shown as stars, whereas fluvial and coastal sands are shown as black circles. Variation fields (expressed by mean and one standard deviation) for upstream, downstream and delta sands are represented by polygons. Arrows represent weathering trends linking the composition of bedrock, grus and soil. 


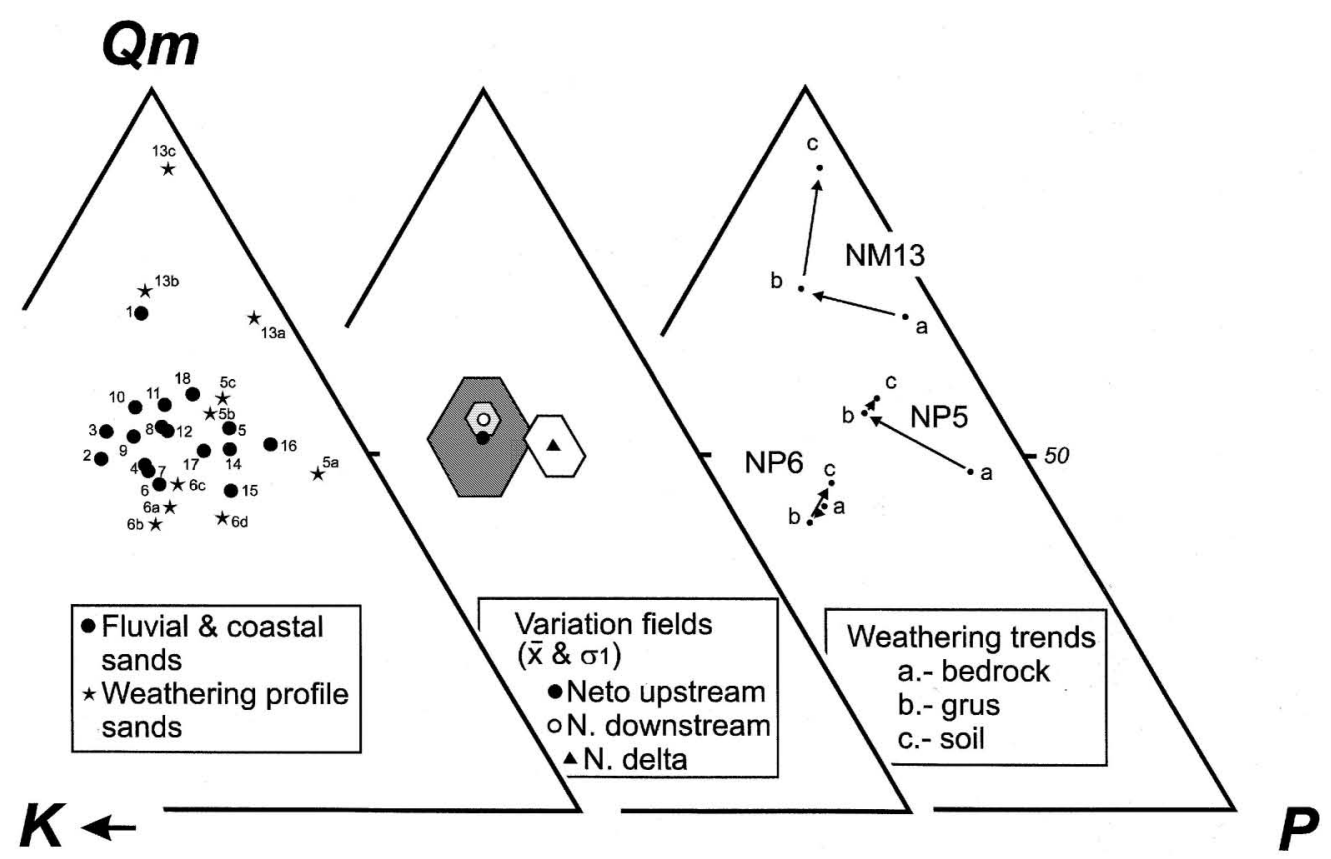

Fig. 5. QmKP diagram. Symbols are the same as those used in Fig. 4. Variation fields (expressed by mean and one standard deviation) for upstream, downstream and delta sands are represented by polygons. Arrows represent the weathering trends linking the composition of bedrock, grus and soil.

The distribution of the five increasing stages of alteration for feldspar grains (Table 3) strengthens the assumptions about compositional trends in the weathering profiles. Plagioclase in bedrock is mainly fresh with 'a' and/or 'b' grain types dominant (Fig. 7). In grus and soil sand fractions, plagioclase shows a progressive increase in the more altered types (c, d and e; Fig. 7). However, this increase is not clear at site NP6, where the distribution of plagioclase types is similar in the bedrock, grus and soil environments. This is probably caused by a weathering-limited denudation regime in this area, resulting from the rapid removal and transport of weathered material from slopes (Carson \& Kirkby, 1972; Johnsson, 1992). The dominant K-feldspar type is the ' $a$ ' in bedrock, grus and soils of the three profiles. This suggests that K-feldspar is not affected by pervasive or sequential transformation into other mineral phases, as is plagioclase. Because a depletion in K-feldspar occurs through the transition from grus to soil, this may be associated with leaching and dissolution, predominantly in the soil environment (Basu, 1981; Nesbitt \& Young, 1984).

\section{Fluvial sands}

Two groups of fluvial sand samples have been considered, depending on their position in the drainage basin (Fig. 2a and b). Upstream samples
(N1 to N7) comprise those from the upper part of the drainage system, where the river cuts across the crystalline bedrock. Downstream samples (N8 to N12) were collected from the lower part of the Neto drainage basin. Sample N10 is from the Vitravo tributary, a basin with minor amounts of crystalline rocks relative to sedimentary rocks (0.9\%; Table 1$)$.

The average composition of upstream sand samples is quartzofeldspathic, with similar quantities of plagioclase and K-feldspar (51-481\%QmFLt; 51-25-24\%QmKP; Figs 4 and 5; Table 2). All samples plot in a cluster, and differences in source lithologies produce little changes in quartz percentage and $\mathrm{P} / \mathrm{F}$ ratios $(0 \cdot 4-$ 0.7). K-feldspar appears as fresh grains (types 'a' and ' $b$ '), but the degree of plagioclase alteration ranges from fresh to completely altered, with a dominance of types 'a', 'b' and 'c' (Table 3). Coarse crystalline rock fragments (Rg; Fig. 6) predominate and represent $>78 \%$ of the total rock fragment population. The presence of finegrained metamorphic rock fragments (Rm; Fig. 6) in samples lacking such rocks in the source area (schist or phyllite; Table 1) is probably the result of derivation from micaschist layers intercalated with gneiss (Amodio Morelli et al., 1976). Sedimentary rock fragments are absent in sands from this portion of the drainage basin; however, dolomite crystals and clay mineral aggregates 


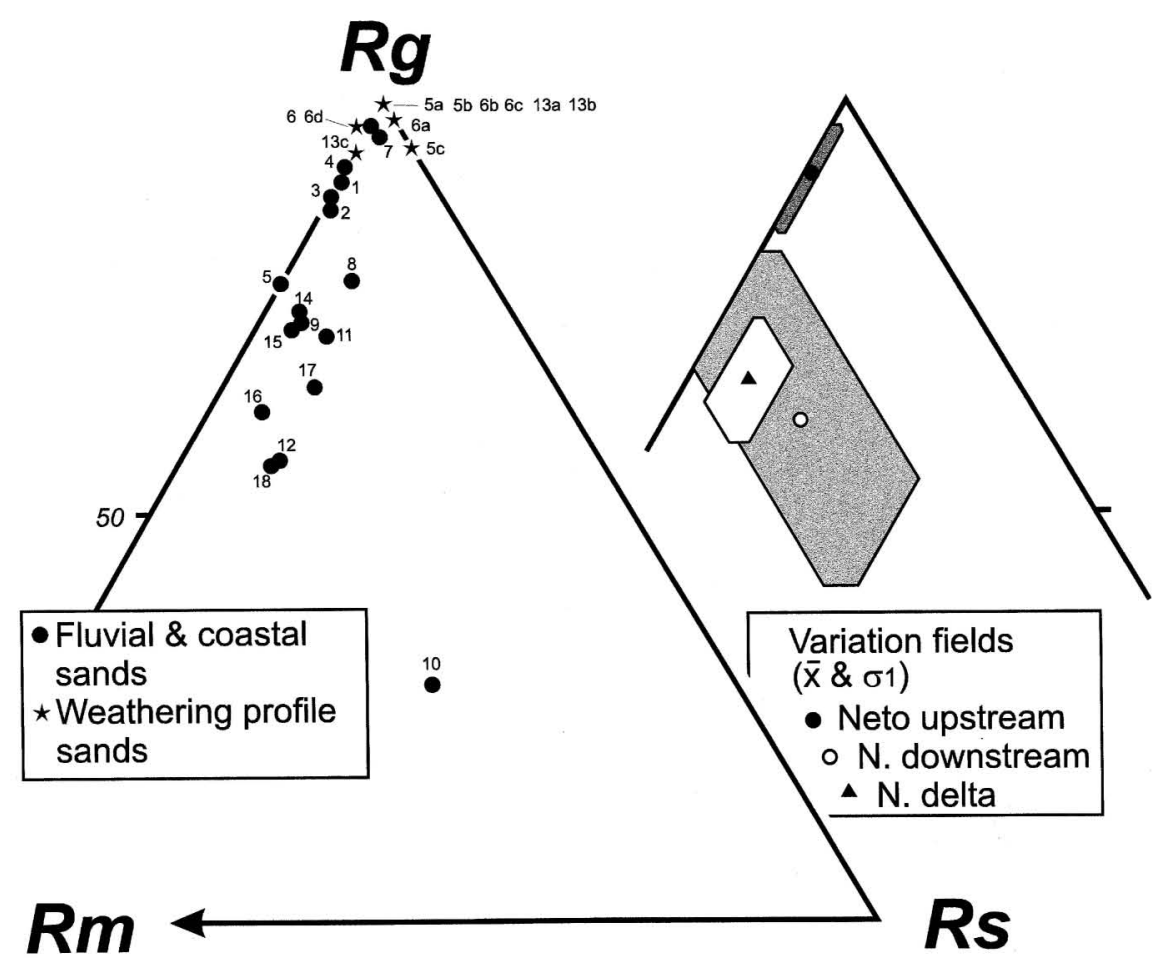

Fig. 6. Rg (plutonic phanerite rock fragments), Rm (metamorphic phanerite + aphanite), Rs (sedimentary phanerite + aphanite) diagram showing composition of the Neto basin sands. Symbols are the same as those used in Fig. 4. Variation fields (expressed by mean and one standard deviation) for upstream, downstream and delta sands are represented by polygons.

Fig. 7. Frequency distribution of feldspar grain alteration stages (five stages from ' $a$ ' to 'e') in the three weathering profiles. Subindex 'a' represents unaltered grains; subindices 'b', 'c' and 'd' include grains composed of less than $10 \%, 10-40 \%$ and $>40 \%$ alteration material respectively; subindex 'e' represents completely altered grains.
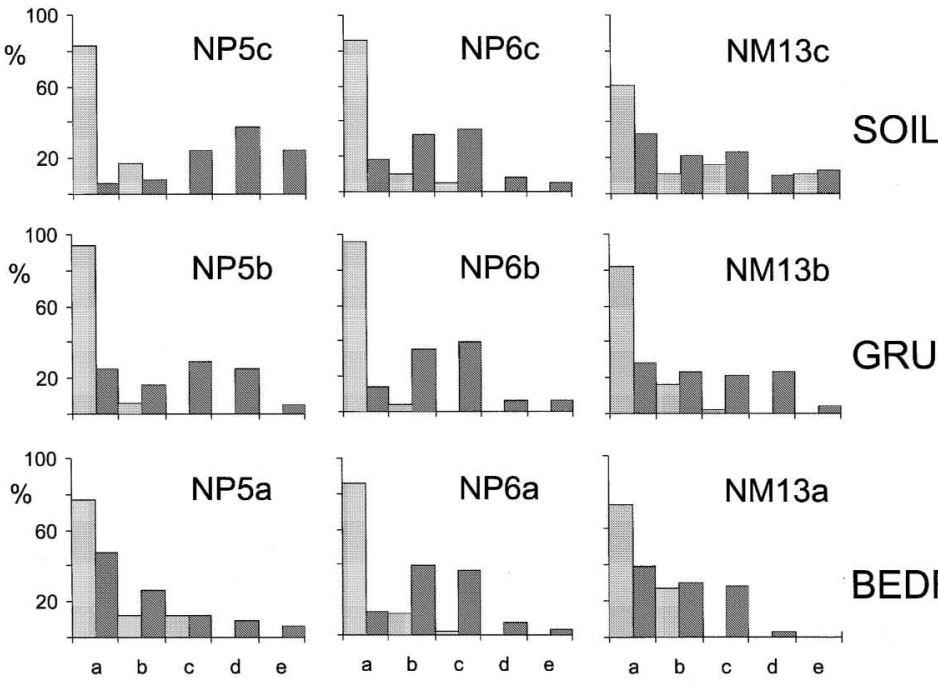

BEDROCK

appear as alteration products after plagioclase. The abundance of dense minerals is higher in the upstream sand than in downstream and delta system sand (Table 2).

Downstream samples (N8 to N12) are also quartzofeldspathic (means of 53-45-2\% QmFLt; 54-23-23\% QmKP), even though their source areas contain large and heterogeneous outcrops of sedimentary rocks (from $10 \%$ to $99 \%$ ). Modal composition differs slightly from upstream sand, showing a larger quartzose (Qm and Qp) population. The population of total lithics (Lt) is heterogeneous, consisting of various types of shale and carbonate fragments. Such variations 
are related to variations in the composition of the sedimentary cover. Small differences in total feldspar occur, but maintain a balance between $\mathrm{K}$ and $\mathrm{P}(\mathrm{P} / \mathrm{F}$ from 0.46 to 0.53$)$. K-feldspar persists as fresh grains, whereas plagioclase includes a greater proportion of altered types than in upstream samples (the sum of 'c', 'd' and ' $e$ ' is generally $>50 \%$ of total plagioclase grains; Table 3). A general increase in metamorphic rock fragments (Rm; Fig. 6) is also a distinctive feature of downstream sand.

On the QmFLt ternary diagram, downstream sand plots within the cluster of data defined by upstream samples (Fig. 4). Such a result implies that little, if any, maturation of medium-grained sand occurred during the recycling of upstream sand to form the analysed downstream samples. Similar results and interpretations are implied by the QmKP data (Fig. 5). In contrast, RgRmRs data show that downstream sand is preferentially enriched in Rs relative to upstream samples (Fig. 6), a result that accurately reflects the recycled origin of downstream specimens (Critelli \& Le Pera, 1994).

Other sedimentary sources, such as lutites and gypsum, show very low preservation potential as detrital products, owing to their lack of mechanical and chemical stability (Zuffa, 1987; Cavazza et al., 1993; Arribas et al., 2000). Thus, only globigerinid fossils may be related to the erosion of Pliocene-Pleistocene lutites and marly lutites. Reworking of alluvial plain sediments also produced little effect on the composition of sand samples. This implies that high sedimentation rates prevented maturation during transport.

\section{Delta sands}

Samples from the Neto delta have a broadly similar modal composition to those analysed from the fluvial system (Figs 4-6); however, they are slightly shifted towards the Lt pole on the QmFLt diagram (Fig. 4). This shift in composition is produced by an increase in labile metamorphic and carbonate-lithic fragments (Table 2). In addition, delta sands are slightly more enriched in plagioclase $(\mathrm{P} / \mathrm{F}=0.62-0.77)$ than are fluvial sands (Fig. 5), whereas the lithic fragment population (Fig. 6) is similar to that of downstream sand, but is less heterogeneous. Many authors have widely reported a depletion of metamorphic lithic fragments in beach sand, where wave action produces rapid and selective destruction of these grains (e.g. Cameron \& Blatt,
1971; McBride \& Picard, 1987; Critelli et al., 1997; Garzanti et al., 1998). In contrast, within the Neto River drainage basin, metamorphic lithic fragments tend to be enriched in distal and beach sand. Such grains are probably supplied to the Neto from nearby fluvial systems containing metamorphic source rocks (e.g. north of the study area). The metamorphic rock fragments are then incorporated into the Neto delta system through the beach environments and longshore currents (Cocco, 1976).

\section{DISGUSSION}

\section{Effects of lithology on sand composition}

To assess whether or not source rocks are the major control on sand composition in the Neto drainage basin, the proportion of major bedrock types within source areas (Table 1) was compared with Qm/F, P/F and Q/Rg (Fig. 8). Because gneiss (Gn) and granite (Gr) represent the dominant bedrock, the ratio of $\mathrm{Gn} /(\mathrm{Gn}+\mathrm{Gr}$ ) (Fig. 8) in the drainage subbasin of each sample is used. If $\mathrm{Gn} /$ $(\mathrm{Gn}+\mathrm{Gr})=1$, then the sampled weathering profile developed on gneiss. However, a value of 0 implies development on granite. In Fig. 8, profiles developed on granite plot on the leftmost vertical axes, whereas those developed on gneiss plot on the rightmost axes. Compositional trends in weathering profiles are indicated by arrows. The first step in the development of a weathering profile (bedrock-grus) involves a slight increase in $\mathrm{Qm} / \mathrm{F}$ and $\mathrm{Q} / \mathrm{Rg}$ and a drastic decrease in $\mathrm{P} / \mathrm{F}$ (e.g. Figs 5a, b and 8, samples 13a to 13b) resulting from alteration of plagioclase by chemical weathering (e.g. Nesbitt et al., 1997). The second step (grus-soil) consists of an enrichment in quartz (a greater increment in $\mathrm{Qm} / \mathrm{F}$ and $\mathrm{Q} / \mathrm{Rg}$ ) and plagioclase, producing a general inversion of the $\mathrm{P} / \mathrm{F}$ trend (e.g. Figs $5 \mathrm{~b}, \mathrm{c}$ and 8 , samples $13 \mathrm{~b}$ to 13a) because of the loss of K-feldspar in the uppermost zone of weathering profiles (e.g. Basu, 1981; Nesbitt et al., 1997).

Plagioclase destruction takes place mainly in the grus horizon, whereas K-feldspar destruction occurs dominantly in the upper part of the weathering profile (soil horizon), suggesting that different processes occur at different levels in the weathering profile. Destruction of K-feldspar in soil horizons may be related to organic activity (e.g. Huang \& Keller, 1972; Basu, 1981; McCarroll, 1990; Moulton \& Berner, 1998). However, intense organic activity in the soil environment can 


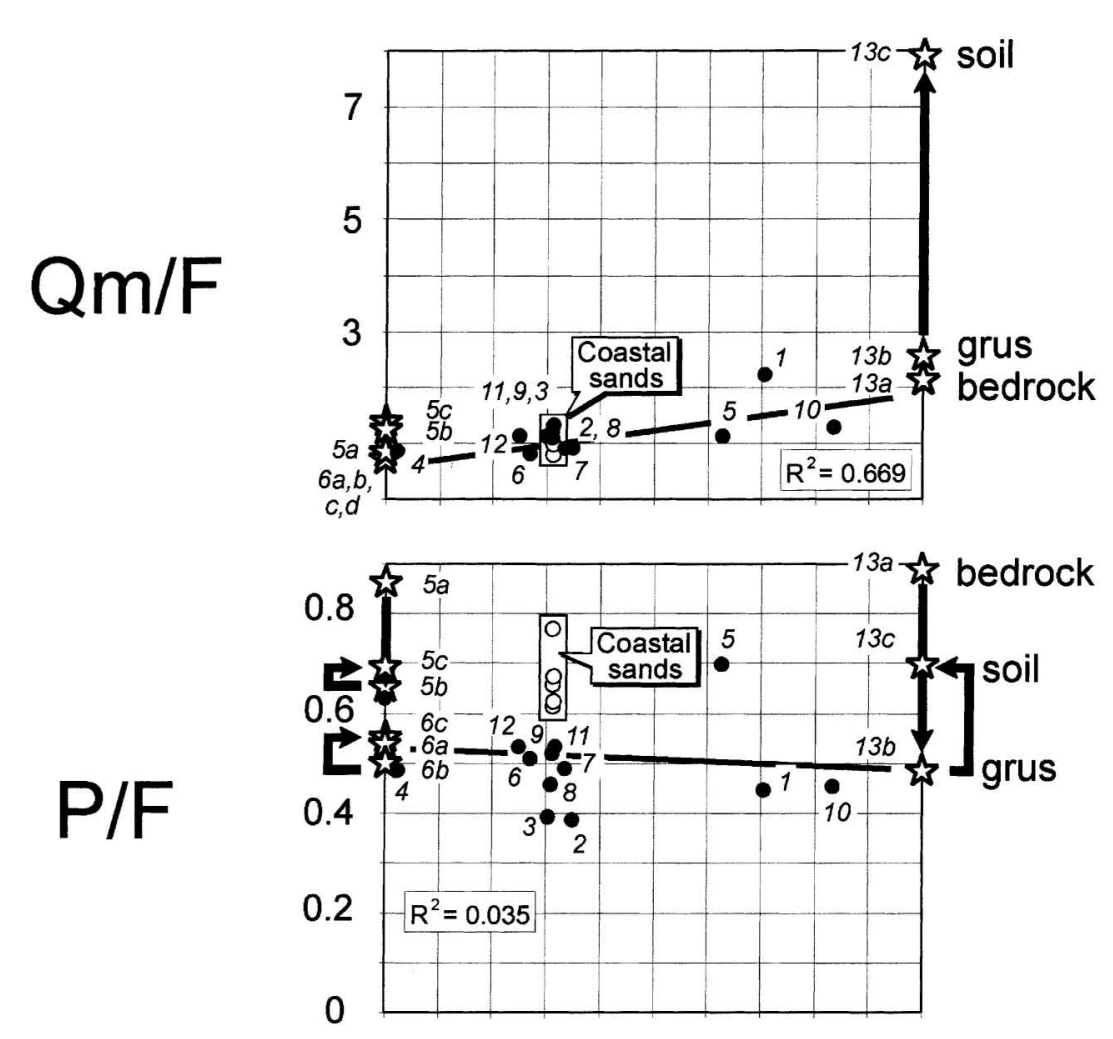

Fig. 8. $\mathrm{Qm} / \mathrm{F}, \mathrm{P} / \mathrm{F}$ and $\mathrm{Q} / \mathrm{Rg}$ compositional indices in weathering profiles (stars), fluvial (black circles) and coastal sands (white circles) vs. the proportion of the main bedrock

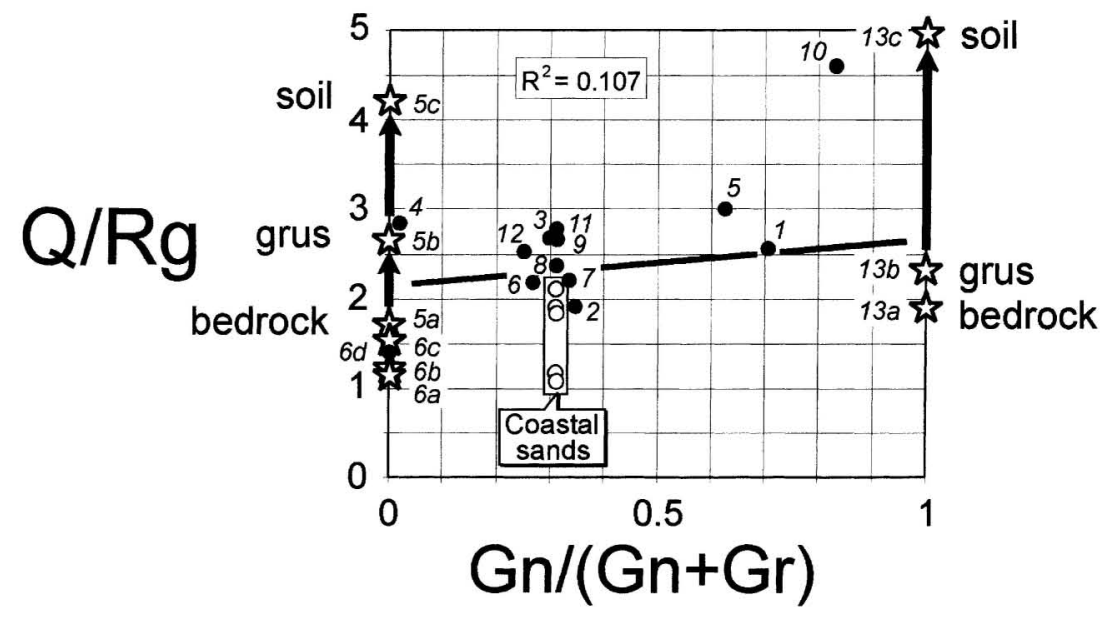
types (gneiss and granite) at the source. Arrows represent the weathering trend from bedrock (a) to grus (b) and soil (c). Regression line and $R^{2}$ values are from grus and fluvial first-cycle sands (coastal and sample N10 are excluded).

initiate the destruction of K-feldspar, even though relicts of altered plagioclase grains remain (Table 3; Fig. 7).

$\mathrm{Qm} / \mathrm{F}, \mathrm{P} / \mathrm{F}$ and $\mathrm{Q} / \mathrm{Rg}$ indices in fluvial sand (Fig. 8) lie between the two extremes discussed in the preceding paragraph, maintaining a nearly direct linear relationship with respect to the surface occurrence of bedrock types. For example, $\mathrm{Qm} / \mathrm{F}$ fluvial data plot about a regression line with $R^{2}=0.669$ (Fig. 8). This relationship suggests that source rocks exert the main control on fluvial sand composition and that differences in source rocks can be detected even when they produce similar sandy products (e.g. gneiss and granite; Palomares \& Arribas, 1993). High maturity (Qm/F, Q/Rg; Fig. 8) of soils developed on gneissic bedrock suggests that such horizons do not play a major role in fluvial sand production, as suggested also by Ibbeken \& Schleyer (1991) for southern Calabrian fluvial sand. The high $\mathrm{P} / \mathrm{F}$ and low Q/Rg (Fig. 8) in the plutonic and gneissic bedrock of the Sila Massif testify to the fact that there is not a direct supply from bedrock (pure mechanical weathering) to generate fluvial sand. However, the composition of fluvial sand appears to be closely related to that of grus (Fig. 8). Grus and fluvial sand composition differ slightly in the $\mathrm{P} / \mathrm{F}$ index, with lower values in fluvial sand. The 
decrease in plagioclase content could be related to the different degrees of alteration of this mineral and K-feldspar in the grus. The latter mineral appears in grus mainly as unaltered grains and could enter the fluvial environment in such a state. However, plagioclase commonly appears in grus as altered grains (Fig. 7). Given the added action of mechanical processes during the incorporation of plagioclase into the fluvial system, it is not surprising that plagioclase appears to be depleted relative to K-feldspar. In fact, the lowest values of the $\mathrm{P} / \mathrm{F}$ index occur in fluvial samples collected from the upstream Neto drainage basin (samples N1 to N4), where there are relatively gentle slopes and a well-developed weathered cover.

Older sedimentary rocks (mainly conglomerate and arkose) also contribute to sand generation in the downstream portions of the Neto River. Erosion of such rocks produces recycled sands with compositions that reflect their plutoniclastic origin (Fig. 8). Note that only sample N10, from a basin underlain by $99 \%$ sedimentary rocks (Table 1), differs from the first-cycle plutoniclastic sands (Fig. 8). Even that sample differs from the first-cycle sands only in the values of $Q / R g$. In fact, the analysis of phaneritic rock fragments (Fig. 6) is the most appropriate method of discriminating first-cycle sands (e.g. Arribas et al., 1990; Critelli \& Le Pera, 1994; Critelli et al., 1997).

Petrographic indices (mainly $\mathrm{P} / \mathrm{F}$ and $\mathrm{Q} / \mathrm{Rg}$ ) in coastal sands differ from those in fluvial sands as a result of contamination of the Neto system by northern coastal drift. In spite of such differences, coastal sands maintain their plutoniclastic character $(\mathrm{Qm} / \mathrm{F})$.

\section{Effects of chemical and mechanical weather- ing, slope and transport on sand composition}

Compositional trends in weathering profiles of the Neto drainage basin are well defined and are in accordance with trends expected for humid to subhumid climates (Nesbitt et al., 1997). Chemical weathering of bedrock reduces the plagioclase content of grus, and granular disintegration is enhanced by biotite breaking along cleavage planes. These processes facilitate mechanical erosion and incorporation of detritus into the fluvial environment. The incorporation of weathered grus into fluvial channels is made easier by steep slopes (Johnsson, 1993; Nesbitt et al., 1997). Granite and gneiss outcrops throughout the Neto drainage system display slopes varying from $17 \%$ to $24 \%$ and from $12 \%$ to $20 \%$ respectively (Table 1). Under these conditions, there is a genetic correspondence between fluvial sand and sand in grus (Fig. 8). As a result, the combination of chemical weathering of the bedrock and mechanical erosion of the grus is essential to explain sediment production in the Neto drainage system. The relations between grus and fluvial compositions could imply that greater volumes of grus are eroded to generate fluvial sands. Therefore, eroded soil material is diluted by the volumetrically major supply from grus horizons. In addition, the greater thickness of grus $(10-70 \mathrm{~m})$ over soil $(0.5 \mathrm{~m})$ may justify the volumetric superiority in supplies from grus and the dilution of soil products.

Relief and mechanical erosion in the Neto basin produce rapid sediment transport and short temporary sediment storage. Thus, chemical weathering during transport appears to be negligible. In the southern Calabria fluvial systems, mechanical disintegration has been considered to be the main mechanism responsible for sand compositional variation during fluvial transport (Ibbeken \& Schleyer, 1991). Figure 9 shows that there is no relationship between values of petrographic indices and the sizes of sampled subbasins. Therefore, mechanical maturation of fluvial sediment during transport in the Neto system is also negligible. The collecting systems of the main course have a network of tributaries with equivalent characteristics in terms of length and relief (Figs 1 and 2; Table 1), and incorporated sediments can be expected to have equivalent petrographic characteristics to those of the main stem. Thus, supplies from tributaries cannot be considered as the 'mask' of chemical and mechanical weathering during transport (Fig. 9).

\section{The Neto sands and other examples of modern plutoniclastic sands}

Modal compositions from plutonic bedrock and derivative fluvial sands from the Neto drainage basin are here compared with plutoniclastic sands derived under different climatic conditions from other mountain ranges (Table 4; Fig. 10).

Upstream sands from the Neto basin are richer in quartz than average bedrock and are therefore shifted towards the quartz apex (NT; Fig. 10). This effect is evidenced by a decrease in the F/Q ratio from 1.22 for the bedrock to 0.81 in the sands (Table 4). Moreover, plagioclase is more unstable during weathering than K-feldspar (Figs 7 and 8), 

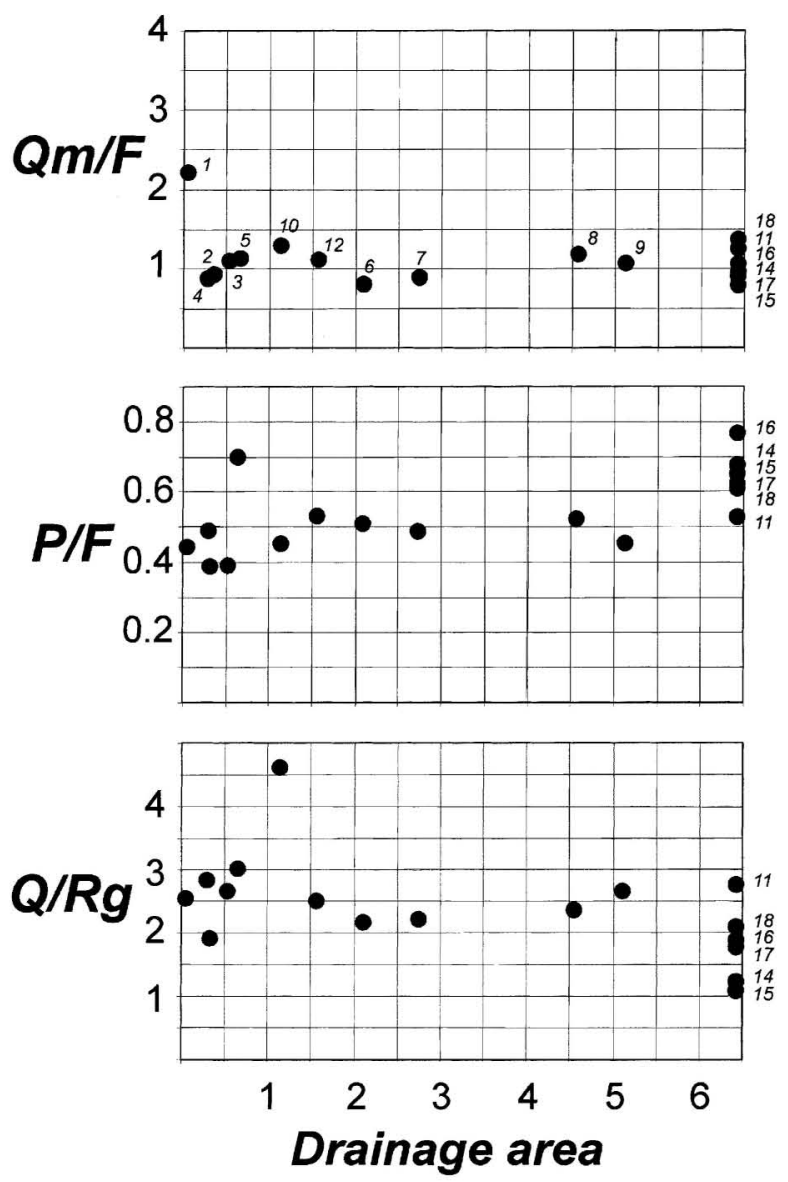

$\left(\mathrm{x} 10^{2} \mathrm{~km}^{2}\right)$

Fig. 9. $\mathrm{Qm} / \mathrm{F}, \mathrm{P} / \mathrm{F}$ and $\mathrm{Q} / \mathrm{Rg}$ compositional indices in the sands vs. the drainage area of the corresponding subbasins.

a fact that has long been recognized (Goldich, 1938; Berner \& Holdren, 1979; James et al., 1981; Cullers et al., 1988; Nesbitt \& Young, 1989). Feldspars are leached and destroyed much more rapidly by acidic solutions in weathering profiles than in fluvial systems with near-neutral waters (Nesbitt \& Young, 1984, 1996). This characteristic seems to apply to the Neto basin, where the main compositional changes in detritus occur principally during formation of the regolith and before erosion (Figs 5 and 8 ).

QmKP compositions (Fig. 10) of mediumgrained fluvial sands derived from Appalachian granite in the USA (Basu, 1976) and from the Bega batholith in the Mallacoota Basin of Australia (Nesbitt et al., 1997) record the highest enrichment in quartz compared with other examples. Compositional trends show that these sands are substantially affected by chemical weathering, and their compositions differ drastically from their source rocks, presumably because of heavy leaching (Table 4). The large shift in composition from source rocks to sands is attributable not only to the humid conditions but also to the low relief of the drainage areas (Fig. 10; Basu, 1976; Nesbitt et al., 1996).

Modern fluvial sands derived from the Rocky Mountains, USA (Basu, 1976), the Rampart Range, USA (van de Kamp \& Leake, 1994), the Central System, Spain (Tortosa, 1988), the Guys Bight Basin, Canada (Nesbitt \& Young, 1996) and the San Gabriel Mountains, USA (Critelli et al., 1997) provide insight into detrital sand modes that are the result of less intense chemical weathering (Fig. 10), because of semi-arid or cold climatic regimes. The Rampart Range sands were derived from basement rock with a composition similar to average Appalachian granite bedrock (Nesbitt et al., 1997), but are much richer in feldspars and contain much less quartz than do the Appalachian sands, plotting very close to the composition of their source. A similar trend is shown by the first-order fluvial sand from the Spanish Central System, where quartz content remains virtually identical to that in the source rocks, with only a slight shift in the plagioclase and K-feldspar contents produced during the transition from weathering to a fluvial environment. The plutoniclastic sand from the Rocky Mountains, the San Gabriel Mountains and the Guys Bight Basin is plagioclase rich, indicating that bedrock has undergone minimal chemical weathering. The high feldspar and quartz contents are nearly identical to bedrock sources, indicating that these sands are produced from relatively unweathered bedrock and not from mantling grus or soils.

The study by Ibbeken \& Schleyer (1991) in southern Calabria (Serre and Aspromonte Massifs) demonstrated that physiography, characterized by short transportation distances and short residence times of detritus within the regolith, controls sediment composition, leading to remarkably immature fluvial sand. Chemical effects of weathering certainly exist (Mongelli, 1993), but are suppressed and diluted by the overwhelming effects of mechanical disintegration (Ibbeken \& Schleyer, 1991). Compositional changes between bedrock and fluvial sand can be monitored by the F/Q ratio, which varies from 1.22 to 1.00 respectively. Sand from the Serre Massif is derived from a granodioritic source and a climate identical to that of the Sila Massif (Table 4). It contains more abundant plagioclase than sand from the upstream portion of the Neto River, indicating erosion from a source with poor weathering 
Table 4. Average QmKP modal composition of some selected plutoniclastic sand suites from different climatic regimes.

\begin{tabular}{|c|c|c|c|c|c|c|c|c|}
\hline Mountain range & Climate & $\begin{array}{l}\text { Mean } \\
\text { annual } \\
\text { temp. } \\
\left({ }^{\circ} \mathrm{C}\right)\end{array}$ & $\begin{array}{l}\text { Mean } \\
\text { annual } \\
\text { rainfall } \\
(\mathrm{mm})\end{array}$ & Qm & $\mathrm{K}$ & $\mathrm{P}$ & $\mathrm{F} / \mathrm{Q}$ & References \\
\hline $\begin{array}{l}\text { Northern Calabria: } \\
\text { Sila Massif* }\end{array}$ & $\begin{array}{l}\text { Warm } \\
\text { temperate } \\
\text { to humid }\end{array}$ & 10-12 & $1500-2000$ & & & & & This study \\
\hline Bedrock & & & & 45 & 17 & 38 & 1.22 & \\
\hline Fluvial sand & & & & 55 & 19 & 26 & $0 \cdot 81$ & \\
\hline $\begin{array}{l}\text { Southern Calabria: } \\
\text { Serre Massif } \dagger\end{array}$ & $\begin{array}{l}\text { Warm } \\
\text { temperate } \\
\text { to humid }\end{array}$ & $10-12$ & $1500-2000$ & & & & & $\begin{array}{l}\text { Ibbeken \& Schleyer } \\
\text { (1991) }\end{array}$ \\
\hline Bedrock & & & & 45 & 17 & 38 & $1 \cdot 22$ & \\
\hline Fluvial sand & & & & 50 & 16 & 34 & 1 & \\
\hline $\begin{array}{l}\text { Australia: Mallacoota } \\
\text { Basin }\end{array}$ & $\begin{array}{l}\text { Warm } \\
\text { temperate } \\
\text { to sub- } \\
\text { humid }\end{array}$ & $5-18$ & 900 & & & & & Nesbitt et al. (1996) \\
\hline Bedrock & & & & 40 & 20 & 40 & $1 \cdot 5$ & \\
\hline Fluvial sand & & & & 70 & 15 & 15 & $0 \cdot 43$ & \\
\hline $\begin{array}{l}\text { Carolina, Georgia: } \\
\text { Appalachian Mts }\end{array}$ & Humid & 18 & $1140-1270$ & & & & & Basu (1976) \\
\hline Bedrock & & & & 27 & 42 & 31 & $2 \cdot 7$ & \\
\hline Fluvial sand & & & & 67 & 26 & 7 & 0.49 & \\
\hline $\begin{array}{l}\text { Baffin Island: } \\
\text { Guys Bight Basin }\end{array}$ & Cool & 4 & $<600$ & & & & & $\begin{array}{l}\text { Nesbitt \& Young } \\
(1996)\end{array}$ \\
\hline Bedrock & & & & 39 & 18 & 43 & 1.56 & \\
\hline Fluvial sand & & & & 40 & 9 & 51 & $1 \cdot 5$ & \\
\hline $\begin{array}{l}\text { Montana, Idaho, } \\
\text { Wyoming: Rocky Mts }\end{array}$ & Arid & 7 & $310-430$ & & & & & Basu (1976) \\
\hline Bedrock & & & & 30 & 20 & 50 & $2 \cdot 33$ & \\
\hline Fluvial sand & & & & 49 & 20 & 31 & 1.04 & \\
\hline Spain: Central System & Semi-arid & $6-14$ & 500 & & & & & \\
\hline Bedrock & & & & 34 & 28 & 38 & 1.94 & Aparicio et al. (1975) \\
\hline Fluvial sand & & & & 34 & 32 & 34 & 1.94 & Tortosa (1988) \\
\hline $\begin{array}{l}\text { Colorado: } \\
\text { Rampart Range }\end{array}$ & Semi-arid & & & & & & & $\begin{array}{l}\text { van de Kamp \& } \\
\text { Leake (1994) }\end{array}$ \\
\hline Bedrock & & & & 27 & 42 & 31 & $2 \cdot 7$ & \\
\hline Fluvial sand & & & & 33 & 39 & 28 & $2 \cdot 03$ & \\
\hline $\begin{array}{l}\text { Southern California: } \\
\text { S. Gabriel Mts }\end{array}$ & Semi-arid & & & & & & & \\
\hline Bedrock & & & & 25 & 15 & 60 & 3 & Ehlig (1981) \\
\hline Fluvial sand & & & & 30 & 14 & 56 & $2 \cdot 33$ & Critelli et al. (1997) \\
\hline
\end{tabular}

*Slope gradient $17-24 \%$. $\dagger 30-64 \%$.

profile development. Variations in topographical slope (Table 4) might play a major role in the production of fluvial sand. In Calabria (Sila and Serre Massifs), the rugged topography mitigates the drastic effect of a humid climate on sand composition, resulting in bedrock-fluvial sand trends being much shorter than for Appalachian (Basu, 1976) and Mallacoota Basin (Nesbitt et al., 1996) sands (Fig. 10).

\section{CONCLUSIONS}

In the Neto drainage basin, characterized by 17$24 \%$ mean slopes and a humid Mediterranean climate, chemical and physical weathering control sediment production from crystalline bedrock. Analysis of petrological data derived from fluvial sands and weathering profiles yields the following conclusions. 
Fig. 10. QmKP diagram illustrating the compositional evolution (from bedrock to fluvial sand) of the Neto drainage basin compared with plutoniclastic sands from other mountain ranges, under different climatic or physiographical conditions.

The grain-size distribution within weathering profiles shows a tendency towards coarse modes $(>2 \mathrm{~mm})$, a relationship that indicates in situ granular disintegration. Such a process yields a product that is prone to chemical attack. Chemical weathering within the Neto drainage basin has decreased the plagioclase content by as much as $17 \%$ as bedrock was converted to grus. In addition, K-feldspar content was decreased by as much as $11 \%$ during pedogenesis on gentle slopes.

A detailed analysis of the alteration stages of feldspars indicates that plagioclase alteration increases from bedrock to soil as weathering progresses, whereas K-feldspar remains generally unaltered or little altered (alteration $<10 \%$ of the whole grain). This implies that leaching and dissolution are the dominant processes responsible for the depletion of K-feldpar during pedogenesis.

The uppermost part of the Neto drainage basin is characterized by outcrops of crystalline rock (plutonites, gneiss), whereas a blanket of sedimentary rocks covers the lower reaches of the basin. Thus, there are multiple sources of fluvial sands throughout the basin. Hence, it is significant that Neto River detrital modes display a nearly homogeneous quartzofeldspathic composition (51-48-1\% QmFLt; 51-25-24\% QmKP in upstream sand; 53-45-2\% QmFLt; 54-23-23\% QmKP in downstream sand; 46-45-9\% QmFLt; 51-16-33\% QmKP in coastal sand). However, first-cycle and multicyclic sand can be discriminated using both aphanitic and phaneritic grain types (90-10-0\% RgRmRs in first-cycle upstream sand; 61-25-14\% RgRmRs in multicycled downstream sand; and 66-27-7\% RgRmRs in coastal sand).
The composition of first-cycle sand in the Neto drainage system is controlled by bedrock type. $\mathrm{Qm} / \mathrm{F}$ ratios are an efficient tool for discriminating between gneissiclastic and plutoniclastic sand. In addition, the ratios of $\mathrm{Qm} / \mathrm{F}$ and $\mathrm{Q} / \mathrm{Rg}$ suggest that fluvial sands were derived from grus rather than from soil horizons. Differences in the $\mathrm{P} / \mathrm{F}$ ratio between fluvial and grus sand may be attributed to mechanical destruction of altered plagioclase during its incorporation into the fluvial system. Consequently, the composition of first-cycle sand diverges from source rock compositions.

The lack of mechanical and chemical maturation, as a result of short and rapid fluvial transport, is shown by a nearly constant sand composition (i.e. $\mathrm{Qm} / \mathrm{F}, \mathrm{P} / \mathrm{F}$ and $\mathrm{Q} / \mathrm{Rg}$ ) along the main channel of the Neto River. Therefore, any compositional maturity of sand in the Neto River is inherited from the source during the development of weathering profiles.

Feldspar-quartz ratios (F/Q) have been widely used to deduce provenance. However, this study demonstrates that this ratio can be highly variable within a single drainage basin developing under humid climatic conditions. In addition, the $F / Q$ ratio, being climatically invariant, is dependent on variations in topographical gradients. Indeed, plutoniclastic sand developed in the southern Calabria fluvial system (Serre Massif) has an F/Q ratio close to that of its source rock, because of high gradients in topographical slopes. As a consequence, the use of the F/Q ratio in sandstone petrological studies must take into account both palaeoclimatic and palaeophysiographic constraints if they are to interpret ancient provenances successfully. 
This work was funded by a Bilateral Italian Consiglio Nazionale delle Ricerche (CNR)-Spanish Consejo Superior de Investigacion Cientificas (CSIC) grant [Project title: 'The effects of lithology, morphology, transport and depositional environment on quantitative provenance of modern sand (Spain, Calabria): implications for geographic distribution of actualistic petrofacies; authors J. Arribas and S. Critelli]. This paper is also a contribution to the Spanish DGICYT project PB93-0178 (grants to J. Arribas), the CNR-Istituto di Ricerca per la Protezione Idrogeologica nell'Italia Meridionale ed Insulare, Rende (CS) and the CNR-Istituto di Ricerca sulle Argille, Tito Scalo (PZ) (grants to S. Critelli). We are grateful to H. Ibbeken, G. Mongelli, V. Perrone, G. Piccarreta, A. Rottura, M. Sorriso-Valvo, R. Valloni and G. G. Zuffa for their constructive discussions of geology, geomorphology, weathering and erosion processes in the Sila Massif and southern Calabria, and to Sedimentology reviewers Gary Girty, Mark Johnsson and Peter Mozley for reviews, helpful discussions and comments on an earlier version of the manuscript.

\section{REFERENCES}

Amodio-Morelli, L., Bonardi, G., Colonna, V., Dietrich, D., Giunta, G., Ippolito, F., Liguori, V., Lorenzoni, S., Paglionico, A., Perrone, V., Piccarreta, G., Russo, M., Scandone, P., Zanettin Lorenzoni, E. and Zuppetta, A. (1976) L'Arco Calabro Peloritano nell'orogene appenninico-maghrebide. Soc. Geol. Ital. Mem., 17, 1-60.

Aparicio, A., Barrera, J.L., Caraballo, J.M., Peinado, M. and Tinao, J.M. (1975) Los materiales graniticos hercinicos del Sistema Central español. Inst. Geol. Min. Esp. Mem., 88, $145 \mathrm{pp}$.

Arribas, J., Gómez-Gras, D., Rosell, J. and Tortosa, A. (1990) Estudio comparativo entre las areniscas Paleozoicas y Triásicas de la Isla de Menorca: evidencias de procesos de reciclado. Rev. Soc. Geol. Esp., 3, 105-116.

Arribas, J., Gritelli, S., Le Pera, E. and Tortosa, A. (2000) Composition of modern stream sand derived from a mixture of sedimentary and metamorphic source rocks (Henares River, Central Spain). Sed. Geol., 133, 27-48.

Banfield, J.F. and Eggleton, R.A. (1990) Analytical transmission electron microscope studies of plagioclase, muscovite, and K-feldspar weathering. Clay Mineral., 38, 77-89.

Basu, A. (1976) Petrology of Holocene fluvial sand derived from plutonic source rocks: implications to paleoclimatic interpretations. J. Sed. Petrol., 46, 694-709.

Basu, A. (1981) Weathering before the advent of land plants: evidence from unaltered detrital $\mathrm{K}$-feldspars in CambrianOrdovician arenites. Geology, 9, 132-133.

Basu, A. (1985) Influence of climate and relief on compositions of sands released at source areas. In: Provenance of Arenites (Ed. G.G. Zuffa), pp. 1-18. D. Reidel, Dordrecht.

Bates, R.L. and Jackson, J.A. (1987) Glossary of Geology, 3rd edn. American Geological Institute, Alexandria.

Berner, R.A. and Holdren, C.R. (1979) Mechanism of feldspar weathering. II. Observations of feldspars in soils. Geochim. Cosmochim. Acta, 43, 1173-1186.

Caggianelli, A., Del Moro, A. and Piccarreta, G. (1994) Petrology of basic and intermediate orogenic granitoids from the Sila Massif (Calabria, southern Italy). Geol. J., 29, 11-28.

Cameron, K.L. and Blatt, H. (1971) Durabilities of sand-size schist and "volcanic" rock fragments during fluvial transport, Elk Creek, Black Hills, South Dakota. J. Sed. Petrol., 41, 565-576.

Carson, M.A. and Kirkby, M. (1972) Hillslope Form and Process. Cambridge University Press, Cambridge.

Cavazza, W., Zuffa, G.G., Camporesi, C. and Ferretti, C. (1993) Sedimentary recycling in a temperate climate drainage basin (Senio River, north-central Italy): composition of source rock, soil profiles, and fluvial deposits. In: Processes Controlling the Composition of Clastic Sediments (Eds M.J. Johnsson and A. Basu), Geol. Soc. Am. Spec. Pap., 284, 247261.

Cleary, W.J. and Connolly, J.R. (1971) Distribution and genesis of quartz in a piedmont-coastal plain environment. Geol. Soc. Am. Bull., 82, 2755-2766.

Cocco, E. (1976) The Italian north Ionian Coast: tendency towards erosion. Mar. Geol., 21, 49-57.

Cosentino, D., Gliozzi, E. and Salvini, F. (1989) Brittle deformations in the Upper Pleistocene deposits of the Crotone peninsula, Calabria, southern Italy. Tectonophysics, 163, 205-217.

Gritelli, S. (1999) The interplay of lithospheric flexure and thrust accommodation in forming stratigraphic sequences in the southern Apennines foreland basin system, Italy. Rend. Fis. Acc. Naz. Lincei, 10, 257-326.

Critelli, S. and Le Pera, E. (1994) Detrital modes and provenance of Miocene sandstones and modern sands of the Southern Apennines thrust-top basins (Italy). J. Sed. Res., 64, 824-835.

Critelli, S. and Le Pera, E. (1998) Post-Oligocene sedimentdispersal systems and unroofing history of the Calabrian Microplate, Italy. Int. Geol. Rev., 40, 609-637.

Critelli, S. and Le Pera, E. (2000) Provenance relations and actualistic petrofacies in an uplifted thrust-belt, northern Calabria, Italy. In: Quantitative Provenance Studies in Italy (Eds A. Basu and R. Valloni), Mem. Descr. Carta Geol. Ital., Special issue (in press).

Gritelli, S., Di Nocera, S. and Le Pera, E. (1991) Approccio metodologico per la valutazione petrografica del grado di alterazione degli gneiss del Massiccio Silano (Calabria settentrionale). Geol. Appl. Idrogeol., 26, 41-70.

Critelli, S., Le Pera, E. and Ingersoll, R.V. (1997) The effects of source lithology, transport, deposition and sampling scale on the composition of southern California sand. Sedimentology, 44, 653-671.

Grook, K.A.W. (1968) Weathering and roundness of quartz grains. Sedimentology, 11, 171-182.

Cullers, R.L. (1988) Mineralogical and chemical changes of soil and stream sediment formed by intense weathering of Danburg granite, Georgia, USA. Lithos, 21, 301-314.

Cullers, R.L., Basu, A. and Suttner, L.J. (1988) Geochemical signature of provenance in sand-size material in soils and stream sediments near the Tobacco Root Batholith, Montana, USA. Chem. Geol. 70, 335-348. 
Dickinson, W.R. (1970) Interpreting detrital modes of greywacke and arkose. J. Sed. Petrol., 40, 695-707.

Ehlig, P.L. (1981) Origin and tectonic history of the basement terrane of the San Gabriel Mountains, Central Transverse Ranges. In: The Geotectonic Development of California (Ed. W.G. Ernst), pp. 253-283. Prentice Hall, Englewood Cliffs.

Folk, R.L. and Ward, W.C. (1957) Brazos River bar: a study in the significance of grain size parameters. J. Sed. Petrol., 27, $3-26$.

Franzinelli, E. and Potter, P.E. (1983) Petrology, chemistry, and texture of modern river sands, Amazon river system. J. Geol., 91, 23-39.

Garzanti, E., Scutellà, M. and Vidimari, C. (1998) Provenance from ophiolites and oceanic allochtons: modern beach and river sands from Liguria and northern Apennines (Italy). Ofioliti, 23, 65-82.

Gazzi, P. (1966) Le arenarie del flysch sopracretaceo dell'Appennino modenese; correlazioni con il Flysch di Monghidoro. Mineral. Petrogr. Acta, 12, 69-97.

Girty, G.H. (1991) A note on the composition of plutoniclastic sand produced in different climatic belts. J. Sed. Petrol., 61, $428-433$.

Goldich, S.S. (1938) A study in rock weathering. J. Geol., 46, 17-58.

Grantham, J.H. and Velbel, M.A. (1988) The influence of climate and topography on rock-fragment abundance in modern fluvial sands of the southern Blue Ridge Mountains, North Carolina. J. Sed. Petrol., 58, 219-227.

Heins, W.A. (1993) Source rock texture versus climate and topography controls on the composition of modern, plutoniclastic sand. In: Processes Controlling the Composition of Clastic Sediments (Eds M.J. Johnsson and A. Basu), Geol. Soc. Am. Spec. Pap., 284, 135-146.

Huang, W.H. and Keller, W.D. (1972) Organic acids as agents of chemical weathering of silicate minerals. Nature, 239, 149-151.

Ibbeken, H. (1983) Jointed source rock and fluvial gravels controlled by Rosin's law: a grain study in Calabria, south Italy. J. Sed. Petrol., 53, 1213-1231.

Ibbeken, H. and Schleyer, R. (1991) Source and Sediment. A Case Study of Provenance and Mass Balance at an Active Plate Margin (Calabria, Southem Italy). Springer-Verlag, Berlin.

Ingersoll, R.V., Bullard, T.F., Ford, R.L., Grimm, J.P., Pickle, J.D. and Sares, S.W. (1984) The effect of grain size on detrital modes: a test of the Gazzi-Dickinson point-counting method. J. Sed. Petrol., 54, 103-116.

James, W.C., Mack, G.H. and Suttner, L.J. (1981) Relative alteration of microcline and sodic plagioclase in semi-arid and humid climates. J. Sed. Petrol., 51, 151-164.

Johnsson, M.J. (1990a) Overlooked sedimentary particles from tropical weathering environments. Geology, 18, 107-110.

Johnsson, M.J. (1990b) Tectonic versus chemical-weathering controls on the composition of fluvial sands in tropical environments. Sedimentology, 37, 713-726.

Johnsson, M.J. (1992) Chemical weathering control on sand composition. In: Encyclopedia of Earth System Science (Ed. W.A. Nierenber), pp. 455-466. Academic Press, Orlando, FL.

Johnsson, M.J. (1993) The system controlling the composition of clastic sediments. In: Processes Controlling the Composition of Clastic Sediments (Eds M.J. Johnsson and A. Basu), Geol. Soc. Am. Spec. Pap., 284, 1-19.

Johnsson, M.J. and Stallard, R.F. (1989) Physiographic controls on the composition of fluvial sands derived from vol- canic and sedimentary terrains on Barro Colorado Island, Panama. J. Sed. Petrol., 59, 768-781.

Johnsson, M.J., Ellen, S.D. and McKittrick, M.A. (1993) Intensity and duration of chemical weathering: an example from soil clays of the southeastern Koolau Mountains, Oahu, Hawaii. In: Processes Controlling the Composition of Clastic Sediments (Eds M.J. Johnsson and A. Basu), Geol. Soc. Am. Spec. Pap., 284, 147-170.

van de Kamp, P.C. and Leake, B.E. (1994) Petrology, geochemistry, provenance, and alteration of PennsylvanianPermian arkose, Colorado and Utah. Geol. Soc. Am. Bull., 105, 1571-1582.

Kittleman, L.R. (1964) Application of Rosin's distribution in size-frequency analysis of clastic rocks. $J$. Sed. Petrol., 34, 483-502.

Le Pera, E. (1998) Relazioni composizionali tra aree fonte e sabbie fluviali, costiere e marine attuali e recenti in Calabria settetrionale. Unpublished $\mathrm{PhD}$ Thesis, University of Bologna, Italy, 2 vols, $278 \mathrm{pp}$.

Le Pera, E. and Sorriso-Valvo, M. (2000a) Weathering, erosion and sediment composition in a high-gradient river, Calabria, Italy. Earth Surf. Proc. Land., 25, 277-292.

Le Pera, E. and Sorriso-Valvo, M. (2000b) Weathering and morphogenesis in a Mediterranean climate, Calabria, Italy. Geomorphology, 34, 251-270.

Le Pera, E., Critelli, S. and Sorriso-Valvo, M. (2001) Weathering of gneiss in Calabria, Southern Italy. Catena, 42, $1-15$.

McBride, E.F. and Picard, M.D. (1987) Downstream changes in composition, roundness, and gravel size in a short-headed, high-gradient stream, northwestern Italy. J. Sed. Petrol., 57, 1018-1026.

McCarroll, D. (1990) Differential weathering of feldspar and pyroxene in an arctic-alpine environment. Earth Surf. Proc. Land., 15, 641-651.

McEwen, M.C., Fessenden, F.W. and Rogers, J.J.W. (1959) Texture and composition of some weathered granites and slightly transported arkosic sands. J. Sed. Petrol., 29, 477-492.

Mann, W.R. and Cavaroc, V.V. (1973) Composition of sand released from three source areas under humid, low-relief weathering in the North Carolina piedmont. J. Sed. Petrol., 43, 870-881.

Messina, A., Compagnoni, R., De Vivo, B., Perrone, V., Russo, S., Barbieri, M. and Scott, B. (1991) Geological and petrochemical study of the Sila Massif plutonic rocks (northern Calabria, Italy). Boll. Soc. Geol. Ital., 110, 165-206.

Mongelli, G. (1993) REE and other trace elements in a granitic weathering profile from "Serre", southern Italy. Chem. Geol., 103, 17-25.

Morton, A.C. and Johnsson, M.J. (1993) Factors influencing the composition of detrital heavy mineral suites in Holocene sands of the Apure River drainage basin, Venezuela. In: Processes Controlling the Composition of Clastic Sediments (Eds M.J. Johnsson and A. Basu), Geol. Soc. Am. Spec. Pap., 284, 171-185.

Moulton, K.L. and Berner, R.A. (1998) Quantification of the effect of plants on weathering: studies in Iceland. Geology, 26, 895-898.

Nesbitt, H.W. and Young, G.M. (1984) Prediction of some weathering trends of plutonic and volcanic rocks based on thermodynamic and kinetic considerations. Geochim. Cosmochim. Acta, 292, 1523-1534.

Nesbitt, H.W. and Young, G.M. (1989) Formation and diagenesis of weathering profiles. J. Geol., 97, 129-147. 
Nesbitt, H.W. and Young, G.M. (1996) Petrogenesis of sediments in the absence of chemical weathering: effects of abrasion and sorting on bulk composition and mineralogy. Sedimentology, 43, 341-358.

Neshitt, H.W., Young, G.M., McLennan, S.M. and Keays, R.R. (1996) Effects of chemical weathering and sorting on the petrogenesis of siliciclastic sediments, with implications for provenance studies. J. Geol., 104, 525-542.

Neshitt, H.W., Fedo, C.M. and Grant, M.Y. (1997) Quartz and feldspar stability, steady and non-steady-state weathering, and petrogenesis of siliciclastic sands and muds. J. Geol., 105, 173-191.

Nir, D. (1983) Man, a Geomorphological Agent. An Introduction to Anthropic Geomorphology. Kluwer Academic Publishers, Dordrecht.

Nossin, J.J. (1972) Landsliding in the Crati Basin, Calabria, Italy. Geol. Mijnbouw, 51, 591-607.

Palomares, M. and Arribas, J. (1993) Modern stream sands from compound crystalline sources: composition and sand generation index. In: Processes Controlling the Composition of Clastic Sediments (Eds M.J. Johnsson and A. Basu), Geol. Soc. Am. Spec. Pap., 284, 313-322.

Roda, C. (1964) Distribuzione e facies dei sedimenti neogenici nel Bacino Crotonese. Geol. Romana, 3, 319-366.

Roveri, M., Bernasconi, A., Rossi, M.E. and Visentin, C. (1992) Sedimentary evolution of the Luna Field Area, Calabria, southern Italy. In: Generation, Accumulation and Production of Europe's Hydrocarbons II (Ed. A.M. Spencer), Eur. Assoc. Petrol. Geosci. Spec. Publ., 2, 217-224.

Schleyer, R. (1987) The goodness of fit to ideal Gauss and Rosin distributions: a new grain size parameter. J. Sed. Petrol., 57, 871-880.

Sorriso-Valvo, M. (1993) The geomorphology of Calabria. A Sketch. Geog. Fis. Din. Quatemaria, 16, 75-80.

Sorriso-Valvo, M. (1997) Landsliding during Holocene in Calabria, Italy. In: Rapid Mass Movement as a Source of Climatic Evidence for the Holocene (Eds J.A. Matthews, D. Brunsden, B. Frenzel, B. Gläser and M. Weiß), ESF Proj. Eur. Paleoclimate Man, Spec. Issue, 12, 97-108.

Sorriso-Valvo, M., Antronico, L. and Le Pera, E. (1998) Controls on modern fan morphology in Calabria, Southern Italy. Geomorphology, 24, 169-187.

Stallard, R.F. (1988) Weathering and erosion in the humid tropics. In: Physical and Chemical Weathering in Geo- chemical Cycles (Eds A. Lerman and M. Meybeck), pp. 225246. Kluwer, Dordrecht.

Suttner, L.J. (1974) Sedimentary petrographic provinces: an evaluation. In: Paleogeographic Provinces and Provinciality (Ed. C.A. Ross), SEPM Spec. Publ., 21, 75-84.

Suttner, L.J., Basu, A. and Mack, G.H. (1981) Climate and the origin of quartz arenites. J. Sed. Petrol, 51, 21-29.

Thomson, S.N. (1994) Fission-track analysis of the crystalline basement rocks of the Calabrian Arc, southern Italy: evidence of Oligo-Miocene late-orogenic extension and erosion. Tectonophysics, 238, 331-352.

Todd, T.W. (1968) Paleoclimatology and the relative stability of feldspar minerals under atmospheric conditions. J. Sed. Petrol., 38, 832-844.

Tortosa, A. (1988) Analisis de las arenas actuales derivadas de rocas granitica del Sistema Central. Aplicacion a Los Estudios de Procedencia. Tesis de Licenciatura, Universidad Complutense, Madrid, 125 pp.

Valloni, R. (1985) Reading provenance from modern marine sands. In: Provenance of Arenite (Ed. G.G. Zuffa), pp. 309-332. D. Reidel, Dordrecht.

Velbel, M.A. (1985) Geochemical mass balances and weathering rates in forested watersheds of the southern Blue Ridge. Am. J. Sci., 285, 904-930.

Versace, P., Ferrari, E., Gabriele, S. and Rossi, F. (1989) Valutazione delle Piene in Calabria. CNR-IRPI Geodata, 30, $232 \mathrm{pp}$.

Zuffa, G.G. (1980) Hybrid arenites: their composition and classification. J. Sed. Petrol., 50, 21-29.

Zuffa, G.G. (1985) Optical analyses of arenites: influence of methodology on compositional results. In: Provenance of Arenite (Ed. G.G. Zuffa), pp. 165-189. D. Reidel, Dordrecht.

Zuffa, G.G. (1987) Unravelling hinterland and offshore paleogeography from deep-waters arenites. In: Deep-Marine Clastic Sedimentology. Concepts and Case Studies (Eds J.K. Leggett and G.G. Zuffa), pp. 39-61. Graham and Trotman, London. 